\title{
Climate Technology, Trade, and the Doctrine of Common Concern
}

The urgency attached to the need for diffusion of LCT $\mathrm{s}^{8}$ is a consequence of its indispensable role in the mitigation of climate change. A habitable climate is a global public good. ${ }^{9}$ Maintaining safe climatic conditions is arguably the toughest cooperation challenge ever faced by the international community since the World Wars. ${ }^{10}$ A number of factors contribute to the complexity of the climate change problem; for example, its all-encompassing nature, the difficulty of pinpointing a critical threshold of catastrophic emission, a commonly perceived negative effect on the interests of domestic economic growth, and the difficulty to represent, also quantify the interests of the future generations. ${ }^{11}$ The challenge of finding a package of workable solutions to all these issues goes to the root of the current inability of the international legal system to provide an adequate framework of response to contain adverse climate change impacts. While there is an international treaty-based body of climate rules, not only does it lack sufficient normative strength, but also the level of influence it exerts upon other relatively stricter regimes (e.g. international trade regulation) is ambiguous. ${ }^{12}$ Therefore, the sense of urgency to spread LCT s is not translated into actual law.

The role of this opening chapter is to lay out a broad factual and theoretical background to assess the above. It has two general segments. The first segment (sections I \& II) supplies a factual context, in particular, the needed levels of

8 For details on the meaning and scope of low-carbon technologies, See section IIB at p. 14 below.

9 Scott Barrett, 'Aggregate Efforts: Global Public Goods That Depend on the Combined Efforts of All States', Why cooperate? : the incentive to supply global public goods (paperback ed, Oxford University Press 2010).

10 Daniel Cole, 'Climate Change and Collective Action' (2008) 61 Current Legal Problems.

11 Harro van Asselt, The Fragmentation of Global Climate Governance: Consequences and Management of Regime Interactions (Edward Elgar 2014) 3-4; Scott Barrett, 'Climate Treaties and Approaching Catastrophes' (2013) 66 Journal of Environmental Economics and Management 235; Scott Barrett, 'Rethinking Global Climate Change Governance'; Simon Caney, 'Cosmopolitan Justice, Responsibility, and Global Climate Change' in Stephen Mark Gardiner and others (eds), Climate ethics: essential readings (Oxford University Press 2010). 
emission mitigation for a safe climate, also the hazards otherwise. The importance of low-carbon technology diffusion and the facilitative role of international trade in that regard is outlined as well. The second segment (sections III \&VI) outlines the legal and theoretical framework, eventually presenting the hypothesis that the goal of building a positive coherence between the trade and the climate rule system will benefit from the integration of the doctrine of Common Concern of Humankind in those systems. Such coherence would further enable the deployment of trade policy measures for the diffusion of low-carbon technologies.

Mitigation of Climate Change: Fact vs. Law

As human-induced changes to the earth's climate were agreed to be a common concern of humankind, ${ }^{13}$ the international community responded by making a binding commitment in 1992 to "[a]chieve, [...] stabilization of greenhouse gas concentrations in the atmosphere at a level that would prevent dangerous anthropogenic interference with the climate system." ${ }^{14}$ Great may it have sounded back then, but the hindsight of almost three decades of failed attempts at making a rule system capable to do just that now brings to mind brave Achilles' fabled struggle to catch up with the Tortoise. ${ }^{15}$ As the scientific forecasts of our long-term future keep getting bleaker, the success to build an effective framework of rules continue to slip away repeatedly. The initial 1992 agreement where the commitment was made was a framework arrangement, waiting to be fleshed out over time. The first attempt to that end was the Kyoto Protocol. Despite its strong obligatory language, the Protocol has been largely unsuccessful in bringing forth necessary emission reduction as the large developed country emitters left the process over time. Coming pages will show that the recent Paris Agreement has not yet been of much effect either.

In stark contrast to the rulemaking challenges, climate scholarship is a thriving field. Scientists report that the risks posed by anthropogenic climate change are dynamic and they affect in many different levels. Not only does unabated emission of greenhouse gases worsen the natural environment, but it also has a further knock-on effect on social and economic ecosystems that depend on

13 For an account of the inception of the expression, see p. 29 onwards.

14 United Nations Framework Convention on Climate Change 1992 (1771 UNTS 107).

15 Nick Huggett, 'Zeno's Paradoxes' in Edward N Zalta (ed), The Stanford Encyclopedia of Philosophy (Spring 2019, Metaphysics Research Lab, Stanford University 2019) <https:// plato.stanford.edu/archives/spr2o19/entries/paradox-zeno/> accessed 25 October 2020. 
those environments. The Intergovernmental Panel on Climate Change (IPCC) periodically collects and communicates information on the 'key risks'16 arising out of human-induced climate change. ${ }^{17}$ These risks are combined together in groups to form five broad types of threats, each communicated by the IPCC as a 'reason for concern'. ${ }^{18}$ These five reasons for concern are - (i) danger to the unique and threatened systems, (ii) extreme weather events, (iii) uneven distribution of impacts, (iv) global aggregate impacts, and (v) large-scale singular events. As a depiction of the risk levels, the figure in the next page (Figure 1) usefully portrays the immediate necessity of additional mitigation efforts. The top panel of the figure shows six different ranges of temperature rise compared to pre-industrial levels due to different levels of greenhouse gas (GHG) concentrations (in $\mathrm{CO}_{2}$-equivalent terms) by the end of this century. The bottom panel shows the way each of the reasons for concern worsens with the increase of average global temperature. Together it is possible to read the figure as a carbon concentration goal for any temperature limitation target (top) and the consequences thereof in terms of global risks (bottom).

The figure above shows that in the case of the global average temperature rising more than $2^{\circ} \mathrm{C}$ above the pre-industrial levels by 2100, 'high' to 'very high'

16 The key risks are those that are widely agreed upon by the experts as having the most severe adverse consequence for the human and socio-ecological systems. A risk becomes 'key' due to its hazardous consequence or the vulnerability of the systems exposed to it. Other factors of consideration to determine 'key risks' are: (i) magnitude of the consequence, (ii) probability of the risk to materialise, (iii) irreversibility of impact and (iv) limited ability of the impacted.

17 These risks are- (i) Risk of death, injury, ill-health, or disrupted livelihoods in low-lying coastal zones and small islands due to storm surges, coastal flooding, and sea-level rise; (ii) Risk of severe ill-health and disrupted livelihoods for large urban populations due to inland flooding in some regions; (iii) Systemic risks due to extreme weather events leading to breakdown of infrastructure networks and critical services; (iv) Risk of mortality and morbidity during periods of extreme heat, particularly for vulnerable urban populations and those working outdoors; (v) Risk of food insecurity and the breakdown of food systems linked to warming, drought, flooding, and precipitation variability and extremes; (vi) Risk of loss of rural livelihoods and income due to insufficient access to drinking and irrigation water and reduced agricultural productivity; (vii) Risk of loss of marine and coastal ecosystems, biodiversity, and the ecosystem goods, functions, and services they provide for coastal livelihoods; (viii) Risk of loss of terrestrial and inland water ecosystems, biodiversity, and the ecosystem goods, functions, and services they provide for livelihoods. Michael Oppenheimer and others, 'Emergent Risks and Key Vulnerabilities' in Christopher B Field and others (eds), Climate Change 2014: Impacts, Adaptation, and Vulnerability - Part A: Global and Sectoral Aspects. Contribution of Working Group II to the Fifth Assessment Report of the Intergovernmental Panel on Climate Change (Cambridge University Press 2014) 1069-1071. 
(a)

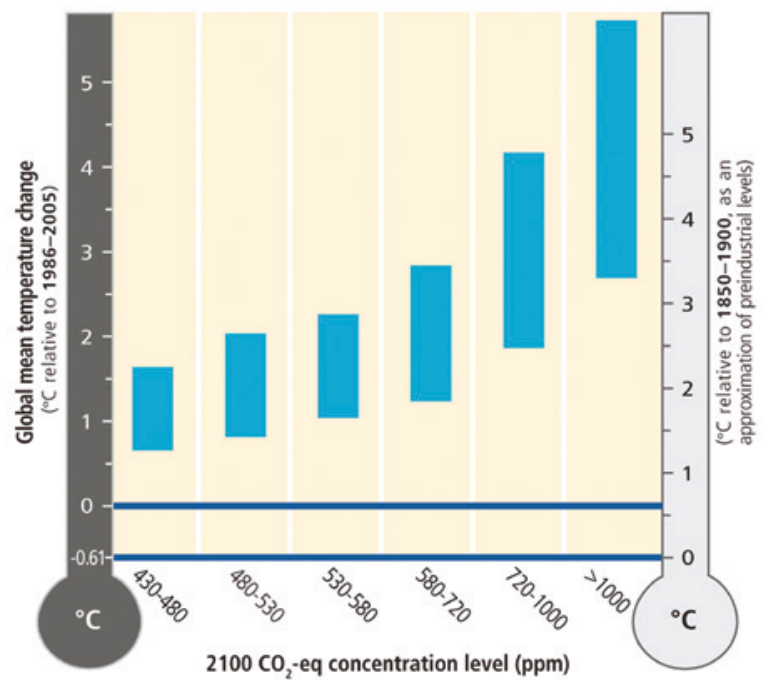

(b)

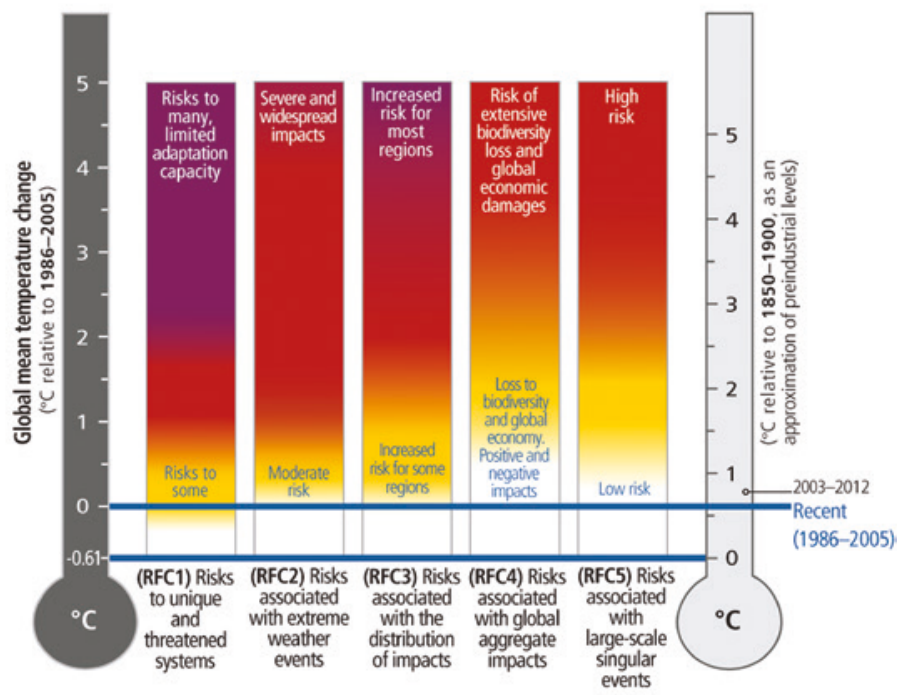

\begin{tabular}{|c|c|c|c|c|c|c|}
\hline \multicolumn{7}{|c|}{ Level of additional risk due to climate change } \\
\hline White & $\begin{array}{l}\text { Whice to } \\
\text { yelow }\end{array}$ & Yellow & relow to to & Red & $\begin{array}{l}\text { Red io } \\
\text { purple }\end{array}$ & Purple \\
\hline Jndetectab & & Moderate & & High & & Verh high \\
\hline
\end{tabular}

FIGURE 1 Reason for concern. Figure 19-7, (n 17) ibid 1082 
risks start setting in. The level of ecosystem damage through the extinction of large fractions of freshwater, marine and terrestrial species will rise with the increasing rate and magnitude of climate change. ${ }^{19}$ Rising marine temperature will also result in the redistribution of global marine resources and loss of marine biodiversity. Increased acidification of oceans will cause loss of the coral reefs and will damage polar ecosystems. ${ }^{20}$ Frequency of submergence, flooding and erosion will continue to increase in the coastal areas as the sea levels will continue to rise well beyond the 21 st century. ${ }^{21}$ The ecosystem impact then affects human livelihood, increasing the existing vulnerabilities of the communities. ${ }^{22}$ As global warming is projected to reduce the surface and ground freshwater resources in the subtropical regions, it will make existing water crises in those regions more acute. An increase of the global average temperature will reduce the yield of staples; for example, wheat, maize and rice in the tropical and temperate regions, worsening the food security conditions. ${ }^{23} \mathrm{Hu}-$ man health will also be adversely impacted as climate change would intensify existing health risks from natural hazards and nutrition loss. All these impacts would affect poor and vulnerable locations many times more than other areas. Besides, climate change will make poverty reduction slow, and sustainable development difficult to achieve for many parts of the globe. ${ }^{24}$

Limiting the adverse impact of climate change is only possible through mitigation up to a scale wherein the cumulative anthropogenic emission of greenhouse gases does not exceed a certain threshold, known as the carbon budget. According to a special report released by the IPCC after the signing of the Paris Agreement, for a $50 \%$ chance of staying within the 1.5 degrees temperature limit, the remaining carbon budget must be about $580 \mathrm{GtCO}_{2}{ }^{25}$ For a $66 \%$ probability, the same must be only around $420 \mathrm{GtCO}_{2}{ }^{26} \mathrm{~A}$ portion of this budget (about $100 \mathrm{GtCO}_{2}$ ) would be automatically exhausted by the natural events already triggered, e.g.

19 IPCC, Climate Change 2014: Synthesis Report. Contribution of Working Groups I, II and III to the Fifth Assessment Report of the Intergovernmental Panel on Climate Change (RK Pachauri, Leo Mayer and Core Writing Team eds, IPCC 2015) 67.

20 ibid.

21 Peter U Clark and others, 'Consequences of Twenty-First-Century Policy for MultiMillennial Climate and Sea-Level Change' (2016) 6 Nature Climate Change 36o.

22 IPCC, Climate Change 2014 (n 19) 69.

23 ibid.

24 ibid 73 .

25 IPCC, 'Summary for Policymakers' in Valerie Masson-Delmotte and others (eds), Special Report: Global Warming of $1.5^{\circ} \mathrm{C}$ (World Meteorological Organization (wм0) 2018) $33<$ http://www.ipcc.ch/report/sr15/> accessed 25 October 2020. ibid. 
thawing of the permafrost and methane emissions from the wetlands. ${ }^{27}$ Almost all climate scientists agree that the current annual rate of consumption of the carbon budget is around $42( \pm 3) \mathrm{GtCO}_{2}$, which means that unless it slows down significantly, the budget would be fully depleted around the 2050s.

Against the backdrop of such bleak forecasts and after much struggle, the international community delivered the Paris Agreement in 2015 - a beacon of hope. ${ }^{28}$ The Agreement is nothing short of a miracle given the level of consensus and ambition it stands for. Just like the 1992 Framework Convention, the Paris Agreement showcases a near universal commitment to climate action. Taking into account the forebodings from the scientific community, the Agreement updated the global emission mitigation target in the following terms:

This Agreement, in enhancing the implementation of the Convention, including its objective, aims to strengthen the global response to the threat of climate change, $[\ldots]$ including by:

a. Holding the increase in the global average temperature to well below $2^{\circ} \mathrm{C}$ above pre-industrial levels and to pursue efforts to limit the temperature to $1.5^{\circ} \mathrm{C}$ above pre-industrial levels, recognizing this would significantly reduce the risks and impacts of climate change; $[\ldots]^{29}$

Nevertheless, the price for a global agreement on an overall mitigation target was paid in the form of legal ambiguities built into the system - so much so that it remains possible to fail to attain the abovementioned target and not break any strict rules of the agreement at the same time. ${ }^{30}$ The mitigation commitment of each participant country is nationally and thus unilaterally determined, albeit subject to an obligation of being progressive over a five years cycle. ${ }^{31}$ Although the parties are encouraged to submit clear, transparent and methodologically consistent commitments, ${ }^{32}$ those submitted in the first round vary widely and hence remain beyond any meaningful comparison. ${ }^{33}$

27 ibid.

28 Paris Agreement 2015 (Report of the Conference of the Parties in its twenty-first session, Decision 1/CP 21, Annex, FCCC/CP/2015/10/Add1).

29 Article 2, ibid.

$30 \quad$ Richard N Cooper and others, 'Why Paris Did Not Solve the Climate Dilemma' in Peter C Cramton, David JC MacKay and Axel Ockenfels (eds), Global carbon pricing: the path to climate cooperation (MIT Press 2017).

31 Article 4, Paris Agreement (n 28).

32 Article 4.8, ibid.

33 This makes tracing of the 'ambitious' elements in the NDC s with respect to a common baseline difficult. United Nations Environment Programme, Emissions Gap Report 2018 (UNEP 2018) 7-15. 
Moreover, detailed guidelines on market-based approaches ${ }^{34}$ to emission mitigation remain up in the air. Further guidance has been detailed in the evolving Paris rulebook, ${ }^{35}$ impact of which will not be witnessed until the second round of commitments come in by $2020 .{ }^{36}$ Given the onset of the global economic downturn in the wake of the COVID 19 pandemic, mitigation is not a priority policy agenda for governments. Moreover, the United States, one of the biggest polluters, has already formally communicated its withdrawal from the Paris Agreement. ${ }^{37}$

The latest IPCC special report is a reminder that even if all the nationallydetermined contributions (NDCs) pledged under the Paris Agreement were duly realised, the global mean temperature would rise about $3^{\circ} \mathrm{C}$ higher than the pre-industrial period by 2100 and would keep rising. ${ }^{38}$ This is again confirmed by the latest UNEP Emissions Gap Report. It shows that meeting all the conditional and unconditional NDC commitments would still see global mitigation fall short by $26-31 \mathrm{GtCO}_{2}$ in 2030 , compared to the level required to reach the $1.5^{\circ} \mathrm{C}$ target. ${ }^{39}$ For all except one of the predicted $1.5^{\circ} \mathrm{C}$ pathways, annual average global emission must remain below $35 \mathrm{GtCO}_{2}$ eq per year, whereas the same average emission according to the current global mitigation commitment is between $5^{2}$ and $58 \mathrm{GtCO}_{2}$ eq. ${ }^{40}$

Clearly, effective response to the global concern of climate change by reaching the adequate levels of mitigation in time will require efforts going beyond the polite suasion of the core climate law system (i.e. the UNFCCC and the

34 Article 6, Paris Agreement (n 28).

35 Information to facilitate clarity, transparency and understanding of nationally determined contributions, referred to in decision 1/CP.21, paragraph 282019 (Meeting of the Parties to the Paris Agreement on the third part of its first session, Decision 4/CMA1, Annex, FCCC/PA/CMA/2018/3/Add1).

36 For more see p. 64 below.

37 Michael R Pompeo, 'On the U.S. Withdrawal from the Paris Agreement' (U.S. Department of State $)<$ https://www.state.gov/on-the-u-s-withdrawal-from-the-paris-agreement/> accessed 25 October 2020.

$38 \quad$ IPCC, 'Summary for Policymakers' (n 25) 24; Jaime Nieto, Óscar Carpintero and Luis J Miguel, 'Less than $2^{\circ} \mathrm{C}$ ? An Economic-Environmental Evaluation of the Paris Agreement' (2018) 146 Ecological Economics 69; UnfCcc, 'Synthesis Report on the Aggregate Effect of the Intended Nationally Determined Contributions' (UNFCCC 2015) Synthesis report FCCC/ $\mathrm{CP} / 2015 / 7$ <http://unfccc.int/resource/docs/2015/cop21/eng/o7.pdf> accessed 25 October 2020; UNFCCC, 'Aggregate Effect of the Intended Nationally Determined Contributions: An Update' (UNFCCC 2016) Synthesis report FCCC/CP/2016/2 <http://unfccc.int/resource/ docs/2016/cop22/eng/o2.pdf> accessed 25 October 2020.

39 United Nations Environment Programme, Emissions Gap Report 2018 (UNEP 2019) 23-25.

$40 \quad$ IPCC, 'Summary for Policymakers' (n 25) 24. 
Paris Agreement). It is highly unlikely that over the next decade, rules of the existing climate regime would succeed in exponentially increasing the parties' level of commitment and ambition. This rising probability of failure triggers the need to look past the traditional limits of the regulatory domain for effective solutions. Like the saying that one must not put all the eggs in the same basket, instead of putting all our hopes on the success of the Paris platform, it would only be prudent to explore for additional and complementary avenues of effective mitigation options, especially in the regulatory realm governing global economic activities.

The domain of the international economic law (IEL) is the most fitting area to search for effective accompaniments to climate rules. IEL is a branch of public international law that covers an ever expanding sphere of transboundary public and private economic activities, ${ }^{41}$ as well as related social issues. This field of law is comprised of areas such as trade, investment, monetary regulations, taxation, related concerns regarding competition, labour welfare, development, and also cross-cutting issues such as multi-level governance and global value chains. ${ }^{42}$ On one hand, some of these activities (e.g. transport emissions) are direct contributors to climate change and therefore must be controlled. On the other hand, IEL offers powerful tools to discipline the behaviour of the different types of actors in the market to curb emissions. Regulatory reforms and policy measures falling within the scope of the IEL can complement climate action by creating new opportunities for climate-friendly production, consumption, and investment choices. So far the disciplines of IEL have remained on the sidelines of international climate action, but this must change. With this motivation, the current research trains its focus on one particular part of the IEL, i.e. international trade regulation under the umbrella of the wTo.

To reflect the need for spreading LCT s for climate mitigation, the rest of the chapter would outline the preliminaries of a coherent trade and climate change rule system to that effect.

41 John Jackson, 'International Economic Law: Reflections on the "Boilerroom" of International Relations' (1995) 10 American University International Law Review 596-599.

42 Jeffrey L Dunoff, 'Subject-matter of International Economic Law' in Thomas Cottier and others (eds), Elgar encyclopedia of international economic law (Edward Elgar Publishing 2017). 


\section{A Technology in Mitigation Pathways}

Although a variety of predicted emission reduction pathways can successfully limit global emission within $1.5^{\circ} \mathrm{C}$, all of those require quick adoption of new technologies at an unprecedented scale, enabling deep decarbonisation of the global economy across all sectors. ${ }^{43}$ Emission pathways that successfully model achievement of the target with limited or no overshoot, are built upon assumptions that include rapid and immediate system changes all across the board, including changes in production and consumption patterns, as well as international cooperation to enhance sustainability and reduce energy demand.

To illustrate, successful emission pathways predict a necessary increase in the share of renewables in electricity generation to be around $70-85 \%$ by $2050 .{ }^{44}$ Within the same time period, the share of coal is expected to go down to virtually zero. The emission from the industry sector is projected to be $75^{-} 90 \%$ lower in 2050 compared to the 2010 levels. ${ }^{45}$ According to the IPCC, sector-specific transitions can be attained through combinations of existing technologies and practices like electrification, product substitution, and techniques of carbon capture and storage. However, deployment of the new technologies at an unprecedented scale is challenging due to economic, financial, and institutional constraints. ${ }^{46}$ In other GHG emitting sectors like transport, buildings, and infrastructure, deep emission cuts require adoption of energy efficiency practices, as well as changes in urban and land planning. For example, the share of low-emission fuel in the transport sector should rise from the current less than $5 \%$ to about $35^{-65 \%}$ by $2050 .{ }^{47}$ Again, such transitions are challenged by economic, institutional, and socio-cultural barriers. ${ }^{48}$

Pathways that attain the $1.5^{\circ} \mathrm{C}$ target while accounting for an initial phase of emission overshoot, are even more dependent on expensive and uncertain carbon dioxide removal ( $\mathrm{CDR}$ ) technologies in the later phases. Instead of immediate decarbonisation, such models predict an emission intensive lifestyle

43 The sectors are: energy, industry, buildings and infrastructure, transport, land usage, and waste.

44 IPCC, 'Summary for Policymakers' (n 25) 17.

45 ibid.

46 ibid 21.

47 ibid 18 .

48 An extensive discussion focusing on the market-related barriers preventing low-carbon technology diffusion can be found in Chapter 2, Section III. at p. 76 below. 
leading up to 2050. Only by an extensive deployment of CDR technologies from that point, negative emission is planned to be reached before other models, thereby resulting in the attainment of the target. The problem is that delayed mitigation allows some of the climate hazards to set in early on-often in regions that were not responsible for those emissions, increasing the burden of climate adaptation. Also, dependence on non-existing CDR technologies assumes technological breakthroughs, which do not happen regularly. ${ }^{49}$

Keeping aside the long-term temperature limitation goals, technologies play a crucial role even to attain the existing insufficient levels of emission reduction commitments registered under the Paris Agreement. According to Brandi, $63 \%$ of all mitigation contributions pledged by the parties under the Paris framework is conditional upon technology transfer. ${ }^{50}$ UNFCCC Secretariat reports that almost all the developing countries mention technology in one form or other in their intended nationally determined contribution (INDC s) documents. ${ }^{51}$ More than 100 developing countries mention the need for technology-related support to be able to pursue their planned commitment. ${ }^{52}$

In sum, appropriate technologies and their global dissemination are an indispensable component for stepping up current and future climate mitigation efforts. In the absence of access to necessary mitigation technologies, not only is it impossible to reach the global mean temperature target set in the Paris Agreement, but also the sustainability of the Agreement itself will be threatened.

\section{B The Concept and Scope of LCTS}

The term 'low-carbon technologies' (LCTs), or alternative formulations ${ }^{53}$ are used in this volume to mean "technologies that aim to minimise greenhouse gas (GHG) emissions, especially carbon dioxide emissions, relative to those

49 Leon E Clarke and others, 'Assessing Transformation Pathways' in Ottmar Edenhofer and others (eds), Climate Change 2014: Mitigation of Climate Change. Working Group III Contribution to the Fifth Assessment Report of the Intergovernmental Panel on Climate Change (Cambridge University Press 2014) 433.

50 Clara Brandi, Trade Elements in Countries'Climate Contributions under the Paris Agreement (International Centre for Trade and Sustainable Development (ICTSD) 2017) < https:// ictsd.iisd.org/sites/default/files/research/trade_elements_in_countries_climate_contributions.pdf $>$ accessed 25 October 2020 .

51 UNFCCC, 'Technology and NDCs' <http://unfccc.int/ttclear/tna/ndcs.html> accessed 25 October $202 \mathrm{O}$.

52 ibid.

53 Alternatively, the expressions 'mitigation techology', 'climate technology', and 'clean technology' has been used throughout the volume to refer to the same notion. 
technologies currently in use in a particular context".54 The notion is somewhat flexible in scope, as it seeks to cover all forms of emission mitigation options. The LCT s can be final products destined for end consumers, capital equipments used for production and processing, and also practical knowledge or skills. ${ }^{5}$ The scope of the notion would therefore comprise of, e.g. tangible products, intangible know-hows, and institutional settings. ${ }^{56}$ Although not a treaty term, low-carbon technology is a notion that is frequently employed by the researchers. Compared to the term 'environmentally sound technology' (EST) used in the treaty language, ${ }^{57}$ low-carbon technology is narrower and focuses exclusively on climate mitigation. It ought to be noted at this stage that this narrow specification is only to maintain analytical rigour. It does not convey any explicit or implicit order of importance or prioritisation of climate mitigation over adaptation.

To a degree, what falls within the domain of appropriate low-carbon technology' for any country depends upon respective overall environmental context (e.g. economic situation, income levels, and position relative to the technology frontier). ${ }^{58}$ The annex at the end of this volume provides a detailed overview of the scope of such technologies as individually identified by many developing countries. Although the list is fairly expansive, there is a degree of convergence in what countries take to be preferred mitigation technology.

The IPCC special report on limiting global warming to $1.5^{\circ} \mathrm{C}$ sheds useful light on the scope of LCT s. For example, power generation from solar, and

54 David Ockwell and Alexandra Mallett (eds), Low-Carbon Technology Transfer: From Rhetoric to Reality (Routledge 2012) 3 .

55 Jørgen Boldt and others, Overcoming Barriers to the Transfer and Diffusion of Climate Technologies (Second Edition, UNEP Risø Centre 2012) 7; Ivan Nygaard and Ulrich Elmer Hansen, 'The Conceptual and Practical Challenges to Technology Categorisation in the Preparation of Technology Needs Assessments' (2015) 131 Climatic Change 371.

$56 \quad$ Nygaard and Hansen ibid 374.

57 Used formally in the UNFCCC Article 4.5, EST s has come to mean "technologies which protect the environment, are less polluting, use all resources in a more sustainable manner, recycle more of their wastes and products, handle residual wastes in a more acceptable manner than the technologies for which they were substitutes, and are compatible with nationally determined socio economic, cultural and environmental priorities". IPCC Working Group III, Methodological and Technological Issues in Technology Transfer: Summary for Policymakers: A Special Report of IPCC Working Group III (Intergovernmental Panel on Climate Change 20oo) $5^{2}$.

$5^{8}$ To give an example, for a less-developed country, end of pipe carbon capture method for a coal-fired power plant may be considered as low-carbon technology. However, this would not be so for a rich economy having access to better ways to mitigate. See Annex for details. 
wind energy has grown dramatically in recent time. To cope with that, the grid systems and storage capacities need to be adapted to the intermittency of renewable energy. ${ }^{59}$ Carbon capture and storage technologies (CCS) are important for fossil-fuel dependent power sectors. In the land usage sector, soil management through conservation agriculture, livestock management, efficient irrigation, and agroforestry reduces emissions overall. The reduction in demand for emission-intensive food items (e.g. meat products) is also useful. Better consumption management to reduce food waste and food loss can further relieve the pressure on food production. ${ }^{60}$ To reduce the amount of energy consumed by urban buildings, the focus remains upon better designs for building heating and cooling, and also on the use of efficient appliances. ${ }^{61}$ Management of urban transport needs using efficient mass transit systems, lowering dependencies on private cars and modal shifts resulting in a lesser need for travel will reduce emissions in that sector, as well as improve urban air quality. ${ }^{62}$ Some domestic aviation can be cut down by high-speed rail connectivity. Also, energy efficiency improvement measures and operational modifications in the industries can contribute to emission reduction. ${ }^{63}$ Lowering emissions in the industrial sector would be feasible when the required capital costs do not raise competitiveness concerns. Energy efficiency improvements can result from general purpose technologies (e.g. information technology), and also from cross-sector technologies (e.g. motor systems, steam systems, recovery of waste heat). Increase in the rate of recycling can also push us towards a more circular economy. ${ }^{64}$

\section{International Trade for Low-Carbon Technology Diffusion}

\section{A Aspects of the Relationship between Trade and Technology}

Technology transfer is often understood only as a legacy claim made by the developing што members to their developed counterparts. ${ }^{65}$ While this is an

59 de Coninck and others (n 1) 324-5; Thomas Cottier and Ilaria Espa (eds), 'Introduction and Overview', International Trade in Sustainable Electricity: Regulatory Challenges in International Economic Law (Cambridge University Press 2017).

60 de Coninck and others ( $\mathrm{n}$ 1) 327-9.

61 ibid 331.

62 ibid 332.

63 ibid 333 .

64 ibid 335-6.

65 For more see pp. 81 \& 85 below. 
important aspect, it is not the whole picture. ${ }^{66}$ The often overlooked fact is that the act of trading between partners across different markets and related cooperation across borders is the biggest conduit for spreading new technologies. Trade triggers cross-border transmission of knowledge in both 'hard' and 'soft' forms, the outcome of which is new products or processes finding markets in the partner economies. ${ }^{67}$ Therefore, transfer of technology also includes situations where multiple stakeholders, both public and private, interact with each other creating flows of knowledge, commodities, and services embodying new technologies. ${ }^{68}$ The IPCC lists a number of pathways through which the stakeholder interactions lead to technology transfer. The list includes, inter alia, direct purchase, licensing, franchising, foreign direct investment, joint ventures, subcontracting, research cooperation, export of products and capital goods, education and training, exchange of scientific and technical personnel, and government assistance programs. ${ }^{69}$ Each of these pathways are categorised by the IPCC as public, private, or community-driven ones, also holding that the private-sector driven pathways are the dominant mode of technology transfer.

In this spontaneous process of technology diffusion, the role of international trade policy, and regulation is facilitative. Domestic tariff and non-tariff measures, as well as global trade rules set the terms of interaction for firms engaged in LCT transactions across borders. By doing so, trade regulation provides the overall framework within which transactions-both voluntary and compulsory-will take place. Therefore, trade rules are important determiners of how a novel technology is taken up by the market actors.

In more theoretic terms, diffusion is a key stage (Figure 2) in a new technology's journey from the drawing board to the market. At that sage, a new technology spreads along different trade-related pathways (e.g. imports, license

66 We discuss the existence and evolution of such legal commitments in the trade and the climate regimes extensively in the Chapter 2, Sections II and IV, below.

67 Boldt and others ( $\left.\mathrm{n}_{55}\right) 12$.

68 IPCC Working Group III (n 57) 51, 55, 6 o.

69 ibid 57; Cristina Tébar Less and Steven McMillan, 'Achieving the Successful Transfer of Environmentally Sound Technologies: Trade-Related Aspects' (2005) Working Paper 2005-2 $<$ https://www.oecd.org/environment/envtrade/35837552.pdf> accessed 25 October 2020; Przemyslaw Kowalski, Daniel Rabaioli and Sebastian Vallejo, 'International Technology Transfer Measures in an Interconnected World' <https://www.oecd-ilibrary.org/trade/ international-technology-transfer-measures-in-an-interconnected-world_ada51eco-en> accessed 25 October 2020; UNCTAD categorises four avenues of technology and knowledge transfer, namely - trade, licensing, FDI, and movement of people. See, Chapter 2, UnCTAD, 'Transfer of Technology and Knowledge Sharing for Development - Science, Technology and Innovation Issues for Developing Countries' (United Nations 2014) UNCTAD/DTL/STICT/2013/8. 


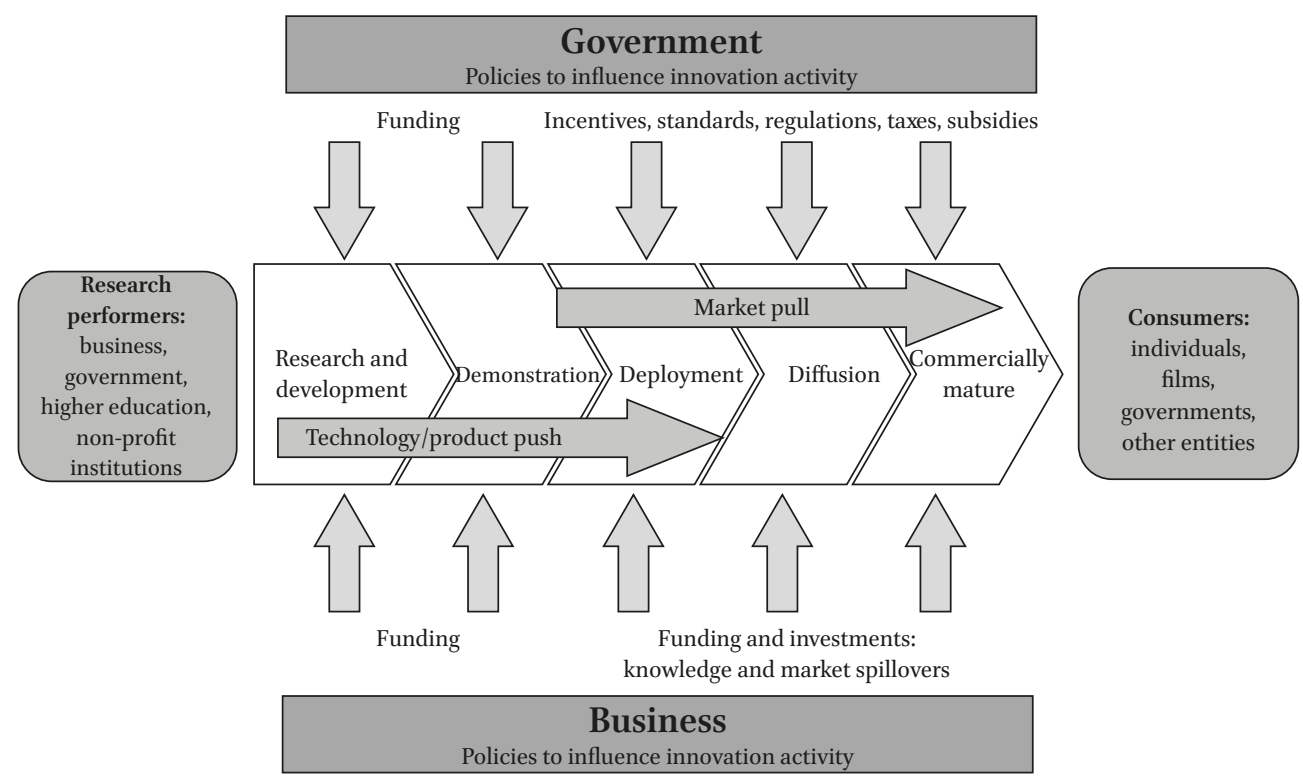

FIGURE 2 The innovation cycle. EGTT, 'Recommendations on Future Financing Options for Enhancing the Development, Deployment, Diffusion and Transfer of Technologies under the Convention' (2009) FCCC/SB/2009/2 8

agreements etc.), given that adequate enabling conditions exist. The following figure shows that while the 'technology push policies' (e.g. R\&D funding, incentives) ensure that a new technology reaches the deployment stage, whether it would progress further or not depends on the existence of appropriate 'market pull' measures. ${ }^{70}$ This is what Gallagher proposes as market formation policies for LCT s. ${ }^{71}$ Therefore, to the extent trade rules are concerned, their role can hypothetically be to allow, also promote such a push and pull dynamic to take place.

Furthermore, economic theory often talks of a 'technique effect'72 arising from increased cross-border trade between partners, which may also

70 de Coninck and others (n 1) 370; Jeffery Atik, 'Technology Transfer' in Thomas Cottier and others (eds), Elgar encyclopedia of international economic law (Edward Elgar Publishing 2017) 606.

71 Kelly Sims Gallagher, The Globalization of Clean Energy Technology: Lessons From China (MIT Press 2014) 16-19. More on this can be found in Chapter 2, pp. 83-84 below.

72 'Trade and Environment - The Impact of Trade Opening on Climate Change' (World Trade Organization $(W T O))<$ https://www.wto.org/english/tratop_e/envir_e/climate_impact_ e.htm\#: :text=Finally\%2C\%2otrade\%2oopening\%2ocan\%2olead,generates\%2o less $\% 2$ ogreenhouse $\% 2$ ogas\%2oemissions.\&text=First $\% 2 \mathrm{C} \% 2$ ofreer\%2otrade\%2o will\%2oincrease,friendly\%2ogoods\%2C\%2oservices\%2oand $\% 2$ otechnologies.> 
potentially influence LCT diffusion. It is predicted that the technique effect may take place in two ways-one is that increase of income would make consumers want products with a lower carbon footprint; the other is that the producers would have access to and adopt better production technologies. ${ }^{73}$ Overall the technique effect may eventually counteract and nullify the growth of the scale of emission due to increased trade. This is the essence of an Environmental Kuznets Curve (EKC). Though theoretically sound, different factors make an actual finding of technique effect difficult. Torras and Boyce argue that technique effect is further dependent on how the income benefit due to trade is distributed throughout the economy. ${ }^{74}$ FernandezAmador and others also do not find the technique effect in the economy. ${ }^{75}$ It may, therefore, suffice to submit that proactive domestic trade policies can help induce low-carbon technology diffusion through triggering the technique effect.

Domestic trade policies are also a relevant issue to reap the technology benefits from the global value chains (GVCs). Cross-border trade in intermediates also involves low-carbon technologies, especially in areas such as the manufacturing of solar photovoltaic (PV) products. While it is true that developing country firms' participation in such supply chains open up possibilities to obtain efficiency improving technologies from the lead firms in developed countries, this does not automatically happen. ${ }^{76}$ The GVC s tend to be semi-independent relationship among businesses where climbing up the

accessed 25 October 2020. Open trade can impact aggregate GHG emissions of an economy through 'scale', 'composition', and 'technique' effects. Scale effect indicates the increase in emission with the economic growth in terms of scale. The composition effect indicates that with increasing sectoral efficiency, overall emission level would be influenced by the compositio of the economy. Lastly the technique effect indicates that energy efficiency improvement due to trade would lower the level of aggregate emissisons. Technique effect is always positive, while the scale effect is otherwise.

73 Ludivine Tamiotti, World Trade Organization and United Nations Environment Programme (eds), Trade and Climate Change: A Report by the United Nations Environment Programme and the World Trade Organization (World Trade Organization; United Nations Environment Programme 2009) 51-53; Octavio Fernández-Amador and others, 'Carbon Dioxide Emissions and Economic Growth: An Assessment Based on Production and Consumption Emission Inventories' (2017) 135 Ecological Economics 269, 270-271; van Asselt (n 11) 159; David I Stern, 'The Rise and Fall of the Environmental Kuznets Curve' (2004) 32 World Development 1419.

74 Mariano Torras and James K Boyce, 'Income, Inequality, and Pollution: A Reassessment of the Environmental Kuznets Curve' (1998) 25 Ecological Economics 147.

75 Fernández-Amador and others (n 73) 274.

76 Unescap, 'Global Value Chains, Technology Transfers and Innovation', Asia-Pacific Trade and Investment Report 2015: Supporting Participation in Value Chains (United Nations 2015) 148,149 . 
chain involves enduring competitive pressures. ${ }^{77}$ Studies show that developing countries falling back in terms of capability improvement remain stuck on low to medium skill-intensive supply chains. ${ }^{78}$ While factors such as obtaining foreign investment, domestic trade openness, and better human capital improve chances of direct technology transfer within the GVC, those factors are themselves dependent on governance reforms, improvement of business environments, and efforts to develop the domestic skill base. ${ }^{79} \mathrm{~A}$ study exploring vertical integration of Chinese firms in solar PV supply chains was possible due to advantageous market policies abroad, mobilization of global talents, flexible manufacturing possibilities at home, and availability of domestic industrial policies. ${ }^{80}$

Two additional arguments can be put forward to further highlight the importance of trade rules in relation to LCT s. One is that supporting the technological upgradation of exporting countries is important particularly for the developed nations to assume full responsibility for their total consumption emissions. Fernandez-Amador and others show that a key reason behind the developed countries' successful reversal of the emission trend is the outsourcing of emissions. ${ }^{81}$ Once the emission inventories of the OECD countries are made to account for the full spectrum of consumption emission, the reversing trend vanishes. The authors recommend adoption of consumption-based trade regulation by the importing countries to account for the emission leakage. Such regulations would also have a technology diffusion benefit as the exporting countries would be further compelled to adopt greater efficiency and mitigation technologies.

Another argument is that trade measures are the best option to tackle price and incentive distortions in the market operating as barriers to the diffusion

77 ibid 149 .

78 Padmashree Gehl Sampath and Bertha Vallejo, 'Trade, Global Value Chains and Upgrading: What, When and How?' (2018) 30 The European Journal of Development Research 481, 498.

79 unesCAP (n 76) 150-158; Satoshi Inomata and Daria Taglioni, 'Technological Progress, Diffusion, and Opportunities for Developing Countries: Lessons from China' in World Trade Organization and others (eds), Technological innovation, supply chain trade, and workers in a globalized world: global value chains development report 2019 (World Trade Organization 2019) 94-96.

8o Fang Zhang and Kelly Sims Gallagher, 'Innovation and Technology Transfer through Global Value Chains: Evidence from China's PV Industry' (2016) 94 Energy Policy 191, 199-200.

81 Fernández-Amador and others (n 73); Octavio Fernández-Amador, Joseph F Francois and Patrick Tomberger, 'Carbon Dioxide Emissions and International Trade at the Turn of the Millennium' (2016) 125 Ecological Economics 14. 
of LCT. These barriers, commonly grouped as market failures, pose great challenges to these technologies' penetration of the market and becoming commercially viable. A known economic phenomenon surrounding a public good, ${ }^{82}$ theoretically market failures affect the diffusion of clean technologies, because - (i) potential users of the technology do not bear the full social cost of non-adoption, or (ii) appropriate information to make the right choice is not present, or (iii) innovators are unwilling to produce ideas that would benefit others. ${ }^{83}$ Trade measures such as pricing of carbon emission or removal of fossil fuel subsidies can correct existing distortions and thereby cure market failures. On a level playing field, actors are then easily attracted towards LCT s. These issues will be further expanded upon in the next chapters.

Before venturing further, one pertinent point ought to be reiterated regarding the scope of this research. This volume focuses on the role of the public international law on trade (i.e. WTO law) and domestic trade policy measures for greater LCT diffusion. It is not meant to prejudice the significance of other important avenues of technology transfer, e.g. cross-border investments, different forms of partnerships, research and development collaborations, and most importantly licensing agreements. ${ }^{84}$ While each of these avenues plays an influential role in clean technology diffusion, current research does not engage with all of those.

In addition, certain caveats should also be kept in notice. When it comes to LCT diffusion, the efficacy of domestic policies to trigger transfers would require complementary actions in non-trade sectors (e.g. education and training), as well as steps from actors beyond the domestic jurisdictions. Moreover, the impact of a trade measure is naturally limited to only trading nations. Countries that are not open to trade, especially poor ones, would need support and assistance to be integrated into any trade-related scheme of technology diffusion. Lastly, trade is a transaction where market size matters. Therefore, it is unavoidable that some countries will be better endowed to deploy specific

82 Kenneth Gillingham and James Sweeney, 'Barriers to Implementing Low-Carbon Technologies' (2012) o3 Climate Change Economics 1250019, 1250019-2. The authors note that 'consumer and producer decision-making in unfettered markets face barriers that lead to less market penetration of low-carbon technologies than would be most economically efficient. We refer to such situations as "market failures."'

83 Adam B Jaffe, Richard G Newell and Robert N Stavins, 'A Tale of Two Market Failures: Technology and Environmental Policy' (2005) 54 Ecological Economics 164; Adam B Jaffe, RG Newell and Robert N Stavins, 'Technological Change and the Environment' in KG Mäler and JR Vincent (eds), Handbook of Environmental Economics, vol 1 (Elsevier Science 2003).

84 See UNCTAD (n 69) above. 
trade tools (e.g. process and production measures) than others. Nevertheless, given the fact that the top GHG emitters are large, well-integrated trading nations, the principal argument of the importance of trade in relation to the diffusion of LCT s remains valid. These issues are again taken up in the third chapter.

\section{B The Disconnect between Trade and Climate Legal Regimes}

There are some basic differences between the treaty regimes of international trade and climate change. The climate change regime tackles the challenge of allocating burdens upon individual state actors to produce shared global benefits, whereas, the trade regime is more transactional, offering exclusive benefits in return for the costs incurred. ${ }^{85}$ This difference between the regimes is also manifested in their orientation towards domestic law. While the Wто rules seek to ensure that domestically adopted measures do not veer off the internationally agreed standards, the domestic commitments are the standard setters for the global climate regime. Finally, the core principles underlying the regimes prioritise different sets of interests. Similar difference is also observable in the motivation of states animating these legal institutions. To illustrate, while non-discrimination is the guiding rule in the trade regime, in climate law it is the principle of common, as well as differentiated responsibilities that carry the day.

As a result, despite the influential role of international trade transactions to facilitate LCT diffusion, the distinct rule systems that govern international trade on one hand and climate change on the other, are disconnected. ${ }^{86}$ The trade rules do not proactively respond to the urgency of combatting climate change. Also, there is no formal appreciation of the role of the regime in spreading low-carbon technologies. ${ }^{87}$ In climate law, trade-related aspects of technology development and transfer never saw clear enunciation, ${ }^{88}$ mainly because of the difficulty in agreeing to a market based approach. De Coninck and Sagar observed recently that "[m]ost developed countries favour an approach that exclusively promotes markets through enabling environments, while most developing countries are of the view

85 Pauwelyn viewed the multilateral trade regime as an amalgamation of bilateral relationships between states. J Pauwelyn, 'A Typology of Multilateral Treaty Obligations: Are WTO Obligations Bilateral or Collective in Nature?' (2003) 14 European Journal of International Law 907 .

86 The next chapter addresses this issue in even greater detail.

87 See Chapter 2 II D at p. 76 below.

88 See Chapter 2 II A at p. 61 onwards. 
that support for developing capabilities, regardless of market-conformity, is also needed." ${ }^{89}$ Institutional idiosyncrasies driven by distinct sets of interests pursued by parties through them contribute to this disconnect. The result, as Humphreys surmises, is 'structural ambiguity'- a situation where the understanding of a term of art (i.e. technology transfer) takes an ambiguous, or irreconcilably different meaning in different regimes. ${ }^{90}$ Over time, this entrenches the divergent approaches of the actors and the regimes towards a common problem.

But the lack of connection between the trade and the climate regimes does not mean that there are necessarily conflicts. The fear of the WTO's antienvironment bias is a thing from the past. The underlying principles in both regimes have lead to repeated attempts in bringing forth a harmonised and complementary coexistence. In the case of the WTO, it is manifest from repeated allusions to the mutual supportiveness of trade openness and environmental protection, giving meaning to sustainable development. ${ }^{91}$ However, the legislative part of the institution did not succeed either in making new rules reflecting trade and environment coherence, ${ }^{92}$ or in initiatives to liberalise trade in environmental goods and services. In contrast, progressive interpretation from the wто Appellate Body (АВ) has developed a predictable jurisprudence to the effect that trade measures can be maintained to promote environmental concerns, given that the opportunity exists in law. In the very second dispute heard by the $\mathrm{AB}$, it was held that wTо laws are not "to be read in clinical isolation

$89 \quad$ Heleen de Coninck and Ambuj Sagar, 'Technology Development and Transfer (Article 10)' in Daniel Klein and others (eds), The Paris Agreement on Climate Change: Analysis and Commentary (Oxford University Press 2017) 261-262.

9o Stephen Humphreys, 'Structural Ambiguity: Technology Transfer in Three Regimes' in Margaret A Young (ed), Regime Interaction in International Law (Cambridge University Press 2012).

91 The parties to the wTо maintained that, '[...] the aims of upholding and safeguarding an open and non-discriminatory multilateral trading system, and acting for the protection of the environment and the promotion of sustainable development can and must be mutually supportive'. 'Doha Ministerial Declaration' (WTO 2001) WT/MIN(O1)/DEC/1 para 6.

92 For details regarding progress on trade and environment cooperation agenda, See, Mereille Cossy and Gabrielle Marceau, 'Institutional Challenges to Enhance Policy CoOrdination - How WTO Rules Could Be Utilised to Meet Climate Objective?' in Thomas Cottier, Olga Nartova and Sadeq Z Bigdeli (eds), International trade regulation and the mitigation of climate change: World Trade Forum (Cambridge University Press 2009); Also, Henrik Horn and Petros C Mavroidis, 'Multilateral Environmental Agreements in the WTO: Silence Speaks Volumes: MEAs in the WTO' (2014) 10 International Journal of Economic Theory 147 . 
from public international law."93 Since then, many environmental instruments have found a way into the factual considerations serving as the background to a better understanding of wTO rules, ${ }^{94}$ in particular, the exception clauses therein.

In the climate regime, a desire to avoid conflict with the trade rules appeared in the language of the 1992 Framework Convention, holding that "[m]easures taken to combat climate change, including unilateral ones, should not constitute a means of arbitrary or unjustifiable discrimination or a disguised restriction on international trade". 95 While obliging the developed countries to mitigate emission, the Kyoto Protocol also urged those countries to do so in a manner that minimises the adverse effect on international trade. Taking a different path in the next decade, the issue of reconciliation with the trade rules was buried in the latest Paris Agreement. ${ }^{96}$

Putting all together, a reasonable conclusion to be drawn is that a coherent, constructive relation between trade and LCT diffusion rules remain an incomplete agenda. Despite fundamental differences, the two regimes exist in the shared plane of public international law without significant conflict-not because the overlap between the two systems are well managed, but because their interactions remain at a bare minimum. The task of coherence building between these two regimes should therefore entail predicting the potential areas of overlap and charting of a path for their integration and co-evolution. We take up these tasks in subsequent chapters. The remainder of the current

93 United States - Standards for Reformulated and Conventional Gasoline [1996] Appellate Body Report WT/DS2/AB/R, DSR 1996:I 317.

94 For example, the AB took note of the Law of the Sea Convention, Biodiversity Convention and the Agenda 21, United States - Import Prohibition of Certain Shrimp and Shrimp Products [1998] Appellate Body Report WT/DS58/AB/R, DSR 1998:VII 2755 48-49; A Panel took note of the wHO classification of asbestos as carcinogenic, European Communities Measures Affecting Asbestos and Asbestos Containing Products [2001] Panel Report wT/ DS135/R, DSR 2001:VII 3305 [8.247]; Another Panel took note of the wHO Framework Convention on Tobacco Control, United States - Measures Affecting the Production and Sale of Clove Cigarettes [2012] Panel Report WT/DS406/R, DSR 2012:XI 5865 [2.29-2.32, 7.229-7.232]; Panel took note of the Agreement on the International Dolphin Conservation Program United States - Measures Concerning the Importation, Marketing and Sale of Tuna and Tuna Products [2012] Panel Report WT/DS381/R, DSR 2012:IV 2013 686; Panel examined whether the UNFCCC has direct effect in India, India-Certain Measures Relating to Solar Cells and Solar Modules [2016] Panel Report WT/DS456/R [7.285-7.301].

95 Article 3.5, United Nations Framework Convention on Climate Change 1992 (n 14).

96 To be noted in this regard that the Paris Agreement does not have any direct reference to trade issues at all. 
chapter will focus on the theoretical aspects of the coherence building and the impact of the doctrine of Common Concern thereupon.

\section{Fragmentation, or Regime Interactions}

The phenomenon of 'disconnect' as outlined above is a result of the fragmentation of the international legal order. Fragmentation is the natural consequence of having multiple specialised rulemaking bodies in a globalising world order, with the corresponding absence of a common coordination mechanism. ${ }^{97} \mathrm{In}$ international relations literature, it is termed as a 'regime complex', referring to the fact of increasing density of international institutions that are not in a hierarchical relationship in a given area-as a result, creating overlaps and potentially giving rise to conflicting rules reflecting different sets of interests. ${ }^{98}$ Both disciplines attribute this phenomenon to the path-dependent rulemaking by institutions in a way that ideas, expectations, and interests animated in different fora are not aligned to generate a set of core applicable norms. ${ }^{99}$ As van Asselt identifies, fragmentation can manifest itself in various ways-as that of rules, or institutions. ${ }^{100}$ With respect to the fragmentation of rules, one can further distinguish between that of primary, and secondary norms. ${ }^{101}$ Fragmentation can also be at the point of governance when one takes into account the increasing role of non-state actors in making rules. ${ }^{102}$ The downsides of having a fragmented legal order, or a regime complex is that it creates opportunities for forum shopping, leads to loss of legal coherence across rule systems,

97 Study Group of the International Law Commission, 'Fragmentation of International Law: Difficulties Arising from the Diversification and Expansion of International Law - Finalized by Martti Koskenniemi' (UNGA 2006) A/CN.4/L.682; A/CN.4/L.702 10-17; Thomas Cottier and others, 'Introduction: Fragmentation and Coherence in International Trade Regulation: Analysis and Conceptual Foundations' in Thomas Cottier and Panagiotis Delimatsis (eds), The prospects of international trade regulation: from fragmentation to coherence (Cambridge University Press 2011) 9-12; Joost Pauwelyn, 'Fragmentation of International Law', Max Planck Encyclopedia of Public International Law (Online, Oxford University Press) <http://opil.ouplaw.com/view/10.1093/law:epil/ 978019923169o/law-978o19923169o-e1406> accessed 25 October 2020.

98 Kal Raustiala and David G Victor, 'The Regime Complex for Plant Genetic Resources' 58 International Organization 277, 295-6.

99 Andreas Fischer-Lescano and Gunther Teubner, 'Regime-Collisions: The Vain Search for Legal Unity in the Fragmentation of Global Law Diversity or Cacophony: New Sources of Norms in International Law Symposium' (2003) 25 Michigan Journal of International Law 999 .

$100 \quad$ van Asselt (n 11) 35-36.

101 ibid 37.

102 ibid 38-39. 
makes consistent rule implementation difficult, and racks up costs of compliance for poor countries. ${ }^{103}$

As argued by Biermann and others, fragmentation cannot be avoided in current world affairs and it need not necessarily be resented. The authors classify forms of fragmentation into synergistic, cooperative, or conflictive depending on the convergence or divergence regarding the number of participating parties, issues covered, and the decision making procedures. ${ }^{104}$ On one hand, there are synergistic fragmentations where the same parties tackle similar issues in institutionally different, but well-integrated regimes - for example, treaty and protocol relationship. ${ }^{105}$ On the other hand are conflictive fragmentations where regimes' memberships, underlying principles, and operating procedures hardly overlap (e.g. Convention on biological diversity and the TRIPS Agreement of the WTO). ${ }^{106}$

Keohane and Victor have also reached similar conclusions while examining the climate change regime complex. Despite the risk of forum shopping, the authors hold that a regime complex is not necessarily undesirable, as different regimes provide a variety of options to build cooperation among smaller groups of actors (i.e. the club approach) in a way that willing participants can make desirable rules. Regime complexes also have higher adaptability over time. ${ }^{107}$ The authors hold that for the climate regime complex to be of a beneficial nature, it needs to be coherent, have clearly discernible normative content based on scientific information, and be accountable, fair, and sustainable. ${ }^{108}$

\section{Paths that Lead to Coherence Building}

Given that fragmentation of international legal regimes is an indispensable reality, it is worthwhile to pursue an agenda of coherence building. It need not be for the appeasement of a postmodern angst, ${ }^{109}$ or with a view to preserve a perceived unified essence of international law. ${ }^{110}$ Coherence is necessary for

\footnotetext{
103 Raustiala and Victor (n 98) 299-303; van Asselt (n 11) 40-42.

104 Frank Biermann and others, 'The Fragmentation of Global Governance Architectures: A Framework for Analysis' (2009) 9 Global Environmental Politics 14, 19-21.

105 ibid 20.

106 ibid 21.

107 Robert O Keohane and David G Victor, 'The Regime Complex for Climate Change' (2011) 9 Perspectives on Politics 7, 14-16.

108 ibid $16-17$.

109 Martti Koskenniemi and Päivi Leino, 'Fragmentation of International Law? Postmodern Anxieties' (2002) 15 Leiden Journal of International Law 553.

110 Martti Koskenniemi, 'Hegemonic Regimes' in Margaret A Young (ed), Regime Interaction in International Law (Cambridge University Press 2012).
} 
international law to be 'responsive'-i.e. able to perform the task the law is set out for. Here we assume that international law must not be construed as incapable to secure the goals states commit to (e.g. containing global temperature rise) through its apparatus (e.g. treaties). The assumption is important to avoid situations of institutionalised paradoxes-outcomes when a regime is illequipped to deliver upon its key mandates. Coherence across regimes, based on shared legal principles, would allow complementarity as one regime can gain access to the specialised tools in other regimes to effectively deliver upon the aspirations of the international community.

Therefore, with respect to LCT diffusion, a coherence building agenda is needed to develop a framework that facilitates low-carbon technology flow and thereby better mitigation performance all over. To the extent such coherence among different regimes does not exist, it needs to be built up. Keohane and Victor suggest that a climate regime complex would be successful if it can allow different regime-specific tools to implement the climate goals in a coherent fashion. ${ }^{111}$ This task of coherence building is of legal nature at its core. It further depends on the nature of the foundational norms and their conflicting or synergistic interactions. In cases where there are explicit legal norms pertaining to the same issue, conflict can arise if action prohibited or regulated under one regime is permitted, even obliged in another. ${ }^{112}$ On the opposite, synergies can exist when regimes are based on shared principles and working towards a common goal. Under both of these circumstances, the fragmentation is manifest. There can also be a potential fragmentation when a principled divergence or convergence among regimes does not actually manifest in conflicts or synergies due to the absence of detailed regulation. ${ }^{113}$ With respect to trade and climate regime fragmentation on the issue of LCT diffusion, it is of a potential nature.

Dispute settlement and techniques of treaty interpretation are of great assistance to resolve explicit, conflicting fragmentations expost. A tribunal called upon to find and apply the law will take recourse to the tools of treaty interpretation and find a resolution of the conflict. Available conflict clauses in the treaties or the rules of priority will help to this end. The last resort is the technique of 'systemic integration'. Made famous by the International Law Commission (ILC) report on the fragmentation of international law, this approach calls for use of Article 31(3)(c) of the Vienna Convention on the Law of Treaties (VCLT) as a tool to integrate systemic objective, by interpreting a norm by

\footnotetext{
111 Keohane and Victor (n 107) 16-18.

112 van Asselt (n 11$) 5^{2-54}$.

113 ibid 54 .
} 
reference to its 'normative environment', i.e. general international law. ${ }^{114}$ The technique put forward in the ILC report is that any rule of international law exists in a systemic relationship with other laws, and therefore, when facing a manifest conflict there is "[...] a need to carry out interpretation so as to see the rules in view of some comprehensible and coherent objective, to prioritise concerns that are more important at the cost of less important objectives."115

However, in cases where there are no rules that manifestly conflict, the above ex post techniques cannot be put into use, necessitating a search for alternatives. As mentioned earlier, the fragmentation between the trade and climate regimes is such a situation. As the climate regime is built on soft law foundations, formal disputes do not arise there. Under such circumstances, preventing fragmentation between regimes becomes a progressive task of filling the potential gaps and constructive ambiguities by creating rules and approaches based on common and shared values. In contrast with the former, this approach is of an ex ante nature. It will involve synergistic rule generation based on constitutionalism and multi-level governance.

The term 'constitution' implies 'a sum of basic legal norms which comprehensively regulate social and political order of a polity'.116 A constitutionalist approach will seek to achieve coherence by establishing a clear system of political order, governance, and normative values. Regarding issues that are at the intersection of two distinct legal regimes, such an approach will put an emphasis on identifying the core shared values, which can then be actualised through generating a complementary set of rules. Based on the constitutionalist foundation, the multi-level governance view envisages the global legal order as composed of different interacting governance layers compensating the domestic loss of regulatory freedom by installing the fundamental values in the international system with the overall goal of preserving and promoting those values. ${ }^{117}$

It is through this lens that the doctrine of Common Concern of Humankind is viewed. The conviction presented here is that the proposed formulation of the doctrine and its implementation can further the work of coherence

\footnotetext{
114 Para 413 Study Group of the International Law Commission (n 97) 208.

115 Paras 417-419 ibid 210-211.

116 Cottier and others, 'Introduction: Fragmentation and Coherence in International Trade Regulation: Analysis and Conceptual Foundations' (n 97) 34; Anne Peters, 'Compensatory Constitutionalism: The Function and Potential of Fundamental International Norms and Structures' (2006) 19 Leiden Journal of International Law 579, 581.

117 Thomas Cottier and Maya Hertig, 'The Prospects of 21st Century Constitutionalism' in Armin von Bogdandy and Rudiger Wolfrum (eds), Max Planck Yearbook of United Nations Law (Koninklijke Brill NV 2003) 261.
} 
building between the trade and climate legal regimes; fostering LCT diffusion as a result. In performing this task, the function of the doctrine is much like the norm of sustainable development; building, also strengthening the regime complex of climate change. The following sections elaborate upon the existing and the proposed dimensions of common concern of humankind, and its potential application regarding the diffusion of LCT s.

\section{Common Concern of Humankind: History and Meaning}

Shared legal concepts are the foundation on which two regimes can develop synergistic interaction. ${ }^{118}$ The common concern of humankind is a unique notion that has informed the climate regime over time. As will be elaborated below, the recognition of climate change as a 'common concern' of 'humankind' legally elevates the issue to a higher plane of urgency and also invites all stakeholders to engage in necessary remedial action. This section will provide a brief background of the concept and propose a meaning in which the concept should be shared across regimes. Suggestions will also be made as to the ways in which this notion, when taken as an emerging doctrine, may contribute to a coherent interaction between the trade and the climate regime regarding LCT diffusion.

Further elaboration of the notion of common concern draws upon the theory of global commons and collective action challenge, as well as takes account of related consequences of unregulated negative externalities leading to market failures. It seeks to find a new balance between a strengthened reach of international law responding to crucial common interests and the traditional regulatory independence of the state under the mantle of permanent sovereignty. By so doing, the doctrine of Common Concern may eventually add to the strength of the related norms, such as the jus cogens and sustainable development.

\section{A Inception and Evolution of the Notion}

The very inception of the phrase 'common concern of humankind' is a politically struck settlement in the late $198 \mathrm{os}^{119}$ at the United Nations General Assembly (UNGA). While on one hand countries were interested in a norm that

\footnotetext{
118 van Asselt (n 11) 55-58.

119 UN Doc A/Res/43/53, adopted on 6/12/1988. Paragraph 1 of the resolution "[r]ecognizes that climate change is a common concern of mankind, since climate is an essential condition which sustains life on earth." This was the first ever use of the concept.
} 
can point out the global interest in preserving and promoting transboundary commons anywhere, an expression was required the usage of which did not connote a potential motive of economic benefit. ${ }^{120}$ The notion of common concern hence emerged as a duty-focused expression underscoring the need for global action with respect to the issue area, while respecting the sovereign domain of states. ${ }^{121}$ Nevertheless, expression of concern does constrain a sovereign entity from acting in a wayward fashion. ${ }^{122}$

Since its inception at the UNGA declaration on climate change, the expression has influenced a number of hard and soft law instruments. ${ }^{123}$ Apart from climate change, it has been used to mark the importance of protection and preservation of biodiversity, ${ }^{124}$ plant genetic resources for food and agriculture, ${ }^{125}$ intangible cultural heritage, ${ }^{126}$ also the relation between environment and development. ${ }^{127}$ The International Law Commission (ILC) vigorously debated whether or not the common concern of humankind can also be considered as a foundational norm in the area of protection of the atmosphere. Eventually, there was a preambular expression of concern, albeit with different

120 This was the reason for not using the expression of Common Heritage of Mankind with respect to climate change, despite the proposition from Malta in the UN General Assembly.

121 Jutta Brunnée, 'Common Areas, Common Heritage, and Common Concern' in Daniel Bodansky, Jutta Brunnée and Ellen Hey (eds), The Oxford Handbook of International Environmental Law (First Edition, Oxford University Press 2007). The author's comment is oft-referred that ' $[t]$ he concept focuses upon the essence of what renders a given concern "common", and treads gingerly around both common property regimes and the territorial sovereignly of individual states'.

122 ibid 566 . The author further conditioned her position by maintaining that '[common concern] signals that states' freedom of action may be subject to limits even where other states' sovereign rights are not affected in the direct transboundary sense envisaged by the no harm principle'.

123 A comprehensive account of the notions evolution can be found here, Shinya Murase, 'Second Report on the Protection of Atmosphere - 67th Session of the International Law Commission' (2015) A/CN.4/681; Also see, Cottier, 'The Principle of Common Concern of Humankind' (n 7); Earlier influential work include, Laura S Horn, 'Common Concern of Humankind and Legal Protection of the Global Environment' (PhD Monograph, The University of Sydney 200o); A A Cançado Trindade and David J Attard, 'I Meeting of the UNEP Group of Legal Experts to Examine the Implications of the "Common Concern of Mankind” Concept on Global Environmental Issues' (1991) 13 Revista IIDH 247.

124 Convention on Biological Diversity (adopted June 5, 1992, entered into force December 29, 1993) UNTS vol. 176o p. 79.

125 International Treaty on Plant Genetic Resources for Food and Agriculture 2001.

126 Convention for the Safeguarding of the Intangible Cultural Heritage 2003.

127 IUCN, Draft International Covenant on Environment and Development (Fourth Edition, 2010). 
wording. ${ }^{128}$ The reasons behind non-inclusion of the norm in the operative part were, inter alia, that there is no state practice to indicate that the term is used with a consistent meaning as was suggested by the special rapporteur. ${ }^{129}$

It is in the growing climate treaty regime that common concern of humankind truly found a home. Not only has the expression played an iconic, and heralding role to the benefit of the budding treaty regime, but it also has activated scholarly contemplation for decades afterwards. In 1992, the preamble to the UN Framework Convention declared that anthropogenic changes to earth's climate are a common concern. ${ }^{130}$ The Washington conference of the International Law Association (ILA) produced an agreed list of principles of the climate regime, where the common concern of humankind was provided with a similar contextual role. ${ }^{131}$ The draft Article 2, titled 'objectives' reiterates the Framework Convention's position as the earth's climatic change and the adverse effect thereof are a common concern of humankind. Prepared by the most noted environmental law scholars, the ILA document serves to clarify the majority position of the experts in this regard.

The Paris Agreement, as well as the decision of the Conference of Parties (COP) containing the Agreement reaffirmed in 2015 that climate change is a common concern of humankind. This reiteration was unique in ways more than one. It puts to question the wisdom behind the earlier reluctance of the ILC in using the expression in relation to the protection of the commons..$^{132}$

128 International Law Commission (ILC), 'Report of the International Law Commission: SixtySeventh Session' (2015) A/70/10 22-27. The expression the ILC chose to refer is 'pressing concern of international community as a whole'. It is interesting to note that while the ILC was very explicit about the non-normative nature of the expression used, in the next sentence it admitted that the commision uses it as a guide for its action, i.e. inclusion of new topic in its work program (page 27). For a critical take, see, Cottier, 'The Principle of Common Concern of Humankind' ( $\mathrm{n}_{7}$ ); Nadia Sanchez Castillo-Winckels, 'Why Common Concern of Humankind Should Return to the Work of the International Law Commission on the Atmosphere' (2016) 29 Geo. Int'l Envtl. L. Rev. 131.

129 International Law Commission (ILC), 'Provisional Summary Record of the 3246th Meeting, Held 6 May 2015' (2016) A/CN.4/SR.3246 See in particular, the intervention by Mr. Murphy; Daniel Bodansky, Jutta Brunnée and Lavanya Rajamani, International Climate Change Law (First Edition, Oxford University Press 2017) 51; Georg Nolte, 'The International Law Commission and Community Interests' in Eyal Benvenisti and Georg Nolte (eds), Community Interests Across International Law (Oxford University Press 2018); Cottier, 'The Principle of Common Concern of Humankind' (n 7) s 1.2.2.2.

130 Preamble, United Nations Framework Convention on Climate Change (n 14).

131 Shinya Murase and others, 'Washington Conference: Legal Principles Relating to Climate Change' (International Law Association 2014) 3-4.

132 International Law Commission (ILC), 'Provisional Summary Record of the 3246th Meeting, Held 6 May 2015' (n 129) 4. One representative at the ILC pointed out that the common concern has not been used in the negotiation since inception.; Georg Nolte later 
Furthermore, the wording of the preambular paragraph in the Paris Agreement also shows a growing normative import. The introductory text of the Agreement mentions:

Acknowledging that climate change is a common concern of humankind, Parties should, when taking action to address climate change, respect, promote and consider their respective obligations on human rights, the right to health, the rights of indigenous peoples, local communities, migrants, children, persons with disabilities and people in vulnerable situations and the right to development, as well as gender equality, empowerment of women and intergenerational equity, ${ }^{133}$

Compared to the previous expressions recognising the common concern of climate change, the above paragraph differs slightly. It is appended with an additional list of issues connected by the obligations of 'respect, promote, and consider'. While on one hand, this could be seen as confusing the scope of the expression and diluting its meaning; on the other hand, it could be seen as an example of its maturity. A plain reading suggests the drafters intend the expression 'common concern of humankind' to trigger climate action, in the course of which the ancillary considerations come to play. ${ }^{134}$

As hinted above, common concern also has a very vibrant life in the scholarly literature. International institutions like the UN Environment (UNEP), also other legal experts have been well invested over time in the growth of this notion. No prominent treatise on environmental law or climate change law is complete without a mention and contemplation on the topic. The existence of the concept has also spread beyond the confines of climate law. This chapter turns next to specify the scope of the concept of common concern.

\section{B Making of a Common Concern}

Though it is already well-accepted that climate change is a common concern of humankind, it is nevertheless useful to recapitulate the path that has led to

admitted that the ILC may have underestimated the utility of the expression, Nolte (n 129) $54-55$.

133 Reference to 'common concern of humankind' in the Paris Agreement preamble appeared in connection with a range of other obligations, including human rights, rights of special groups and right to development. Paris Agreement (n 28).

134 Castillo-Winckels (n 128) 142-143; Zaker Ahmad, 'Trade Related Measures to Spread LowCarbon Technologies: A Common Concern Based Approach' in Thomas Cottier (ed), The Prospects of Common Concern of Humankind in International Law (Cambridge University Press 2021). 
this outcome; especially because the exercise elucidates the key attributes of a shared problem amounting to a common concern. This then informs the task of taking appropriate responses thereto and translating the same into legal language. Also when the notion of common concern is sought to be employed from one legal regime to another as a shared concept, clarity is necessary not only for application but also to delimit the influence of the concept in the other regime.

Formal designation of an area of shared interest as a common concern of humankind is a function of objective and subjective variables. Objectively, the attributes of a problem should be definable as a 'concern' that is 'common'. Subjectively, the dictates of political expediency would determine whether the governments would agree on such a decision. These are detailed below.

The objective variable is literal at the outset, surrounding the meaning of the phrase 'concern' that is common to 'humankind'. Based on the translation of the notion in several languages, Thomas Cottier concluded that "[c]oncern not merely describes a fact, a problem and adverse effects, but equally entails a normative component that the matter needs to be addressed". ${ }^{135}$ Therefore, marking an issue as a common concern does not only underscore an agreement that the issue is worrisome, but also attaches great importance to it, and urges the stakeholders to address the matter. ${ }^{136}$ Through a comparative reading of the relevant preambular recitals of the biodiversity and climate change conventions, Duncan French concludes that a subject-matter earns the significance of common concern of humankind when there is a large consensus that the level and scale of the problem impacts humanity at large, including future generations. ${ }^{137}$ Also, French notes that assigning of concern is important to take the issue out of the "conceit of an exclusive domestic domain" and to put it as a matter of global interest. ${ }^{138}$

Another aspect of the objective component is to attempt to glean the essential characteristics of a common concern by finding a common denominator among the range of problems where the notion has been formally invoked. In that regard, the starting point is that common concerns arise when global

\footnotetext{
135 Cottier, 'The Principle of Common Concern of Humankind' (n 7) s 1.3.3.

136 ibid.

137 Duncan French, 'Common Concern, Common Heritage and Other Global(-ising) Concepts: Rhetorical Devices, Legal Principles or a Fundamental Challenge?' in Michael Bowman, Peter Davies and Edward Goodwin (eds), Research Handbook on Biodiversity and Law (Edward Elgar 2016) 345 .

138 ibid $343-344$.
} 
common is adversely affected. ${ }^{139}$ Friedrich Soltau, after consulting a number of resources, supplied three fundamental characteristics of common concerns of humankind. Those are - first, that the interests in question are transboundary and "touch on values or ethics of global significance"; second, that the interests are of concern because of the gravity of the threat, or potential irreversibility of the impact; third, that it is not possible to safeguard the interests of concern without collective action. ${ }^{140}$ We will see later that the formulation of Common Concern of Humankind advanced as a doctrine further develops the objective parameters as independently verifiable constructs. ${ }^{141}$

Turning to the subjective variable, all the issue areas that have received a formal designation as a 'common concern of humankind' share the seal of political approval in common. Not only do the subject-matters falling within the current formal scope of the term vary to some extent, but also there are pertinent subject-matters that have, despite being logically worthy, not formally received the designation. ${ }^{142}$ There also are areas that have expressions that resemble common concern either in wording or in effect. ${ }^{143}$ This suggests that the influence of the notion beyond the recognised treaty regimes like climate change remains in flux and would indeed benefit from a structured plan of growth.

The involvement of the political factor in the establishment of a common concern of humankind can limit its import across other regimes where the notion is not agreed upon. It is without doubt that in the climate regime common concern of humankind is a core notion that influences the development and operation of particular principles and rules. However, there is only very limited possibility that this shared concern and related need for action would

139 For example, in the UN Framework Convention on Climate Change, its not the climate, rather the anthropogenic change of it is declared a common concern. Brunnée, 'Common Areas, Common Heritage, and Common Concern' (n 121) 564-565.

140 Friedrich Soltau, 'Common Concern of Humankind' in Cinnamon P Carlarne, Kevin R Gray and Richard G Tarasofsky (eds), The Oxford handbook of international climate change law (First edition, Oxford University Press 2016) 207-208.

141 See p. 33-4 below.

142 Cottier, The Prospects of Common Concern of Humankind in International Law (n 5). Each of the chapters from 3 to 8 of this volume deals with specific issue areas that can objectively be considered as common concerns. French (n 137). French notes that desertification can be a candidate for being termed as a common concern of humankind.

143 Judith Schaeli, 'Marine Plastic Pollution as a Common Concern of Humankind' in Thomas Cottier (ed), The Prospects of Common Concern of Humankind in International Law (n 5). Schaeli traces normative consequences similar to that of the common concern in the UN Law of the Sea (UNCLOS) convention. However, as the author pointed out, the UNCLOS does not refer to marine pollution as common concern of humankind. 
spontaneously spill over onto other treaty regimes, like for example, the WTO laws. As will be discussed in subsequent chapters, the ability to take trade policy measures to foster diffusion of LCT $\mathrm{s}$ can be impacted by such a limitation of the notion's cross-regime influence. The proposed doctrine of Common Concern admits the importance of the process of 'claims and responses' - taking place among the key stakeholders, eventually garnering political clout. ${ }^{144}$

\section{Legal Consequence}

Scholars, especially experts on environmental law have at length pored over the possible implications of common concern of humankind as a legal expression. In contrast to the reluctance of the ILC in admitting any legal implication arising from the designation, most experts writing on the topic agree to its having some normative effect. However, as to the extent of the capacity of common concern to trigger legal consequences, opinions vary. While some note the indeterminacy of the exact content of the expression, ${ }^{145}$ as well as doubt its independent existence in the absence of a treaty framework; ${ }^{146}$ there are also optimistic perspectives that see the notion gradually developing into a legal doctrine or a principle of customary international law. ${ }^{147}$ This section will briefly cover the generally shared view among experts on the legal consequences of common concern. Building upon this, the next section will elaborate upon the proposed doctrine of Common Concern of Humankind-a forward-looking structure advanced by Thomas Cottier and others. 148

At the very initial stage, a meeting of experts convened by the UNEP in the run-up to the UNFCCC convention saw a wide range of views regarding the meaning and possible implication of common concern of humankind. It was highlighted that the notion could be applied not only to environmental problems but also beyond. ${ }^{149}$ The note from the UNEP secretariat envisaged

\footnotetext{
144 See p. 46 below.

145 Patricia W Birnie, Alan E Boyle and Catherine Redgwell, International Law and the Environment (3rd ed, Oxford University Press 2009) 129-130.

146 Brunnée, 'Common Areas, Common Heritage, and Common Concern' (n 121); Daniel Bodansky, Jutta Brunnée and Lavanya Rajamani, 'Climate Change and International Law', International climate change law (First Edition, Oxford University Press 2017) $5^{1-52}$.

147 Thomas Cottier and others, 'The Principle of Common Concern and Climate Change' (2014) 52 Archiv des Völkerrechts 293; Cottier, 'The Principle of Common Concern of Humankind' (n 7); Frank Biermann, '„Common Concern of Humankind “: The Emergence of a New Concept of International Environmental Law' (1996) 34 Archiv des Völkerrechts $426,446-45$ o.

148 Cottier, The Prospects of Common Concern of Humankind in International Law (n 5 ).

149 Laura Horn, 'Climate Change and the Future Role of the Concept of the Common Concern of Humankind' (2015) II Australian Journal of Environmental Law 33, 28.
} 
an obligation to cooperate stemming from the concept and involving all countries. ${ }^{150}$ The following expert discussion ${ }^{151}$ posited the expression of common concern in the chain of the evolution of common interest in international law, which saw to reduced domestic jurisdiction and also the emergence of erga omnes obligation. ${ }^{152}$ It was noted that what would be elements of common concern could be detected in different doctrines, e.g. those of res communis, international public domain, and public trust. ${ }^{153}$ Constitutive elements of common concern were identified to be - (i) involvement of all state, and non-state actors, (ii) long-term temporal dimension with intergenerational issues, and (iii) burden-sharing. ${ }^{154}$ The issues of intergenerational equity and equitable burden-sharing in the discharge of a concern was especially highlighted. ${ }^{155}$

The unquestionable core implication of common concern of humankind is introducing a responsibility to act upon the international community in general. ${ }^{156}$ This responsibility obligates the international community to cooperate in response to the concern. ${ }^{157}$ International cooperation triggered by common concern is geared towards the establishment of appropriate institutional and normative framework, built upon the principle of equitable sharing of benefit and burden. ${ }^{158}$ Tracing the growth of the climate legal regime towards a decentralised, bottom-up process guided by domestic preferences of the stakeholders, Jutta Brunée argued that instead of enforcing rules in a strictly top-down

150 Mostafa K Tolba, "The Implications of the "Common Concern of Mankind" Concept on Global Environmental Issues' (1991) 13 Revista IIDH 237, 243.

151 Participants in the discussion were, inter alia, Judge Manfred Lachs, Professor (later Judge) Cançado Trindade, and Professor (later Member of the IT Los tribunal) David Attard.

152 Barcelona Traction, Light and Power Company, Limited (Belgium v Spain); Second Phase [1970] ICJ Rep 19703 (International Court of Justice (ICJ)) 32; Trindade and Attard (n 123) 248.

153 Trindade and Attard (n 123) 248.

154 ibid 249 .

155 ibid 250.

156 Alexandre Kiss, 'The Common Concern of Mankind' (1997) 27 Environmental Policy and Law 244, 246-247. Kiss maintained that common concern, as a concept supplies the basis for the international community to act. Such right and duty of the international community to be concerned requires to be balanced with national sovereignty. Many years later, Shelton echoed the same position,; Dinah Shelton, 'Common Concern of Humanity' (2009) 5 Iustum Aequum Salutare 33, 38; Michael Bowman, 'Environmental Protection and the Concept of Common Concern of Mankind', Research Handbook on International Environmental Law (Edward Elgar Publishing 2010) 503.

157 Brunnée, 'Common Areas, Common Heritage, and Common Concern' (n 121 ) 566.

158 ibid. 
fashion, cooperative facilitation of compliance is the key consequence to be drawn from common concern. ${ }^{159}$

Even though scholars concur that the responsibility arising from a recognised common concern has an erga omnes character, ${ }^{160}$ its actual operation is difficult in practice. As the responsibility is understood to be commonly held by the international community, transforming it to individualised duties upon states amenable to be invoked by others is met with scepticism. There is an apprehension shared by environmental lawyers, especially those specialising in climate change, regarding strictly defined duties. As experience with the Kyoto Protocol suggests, strict duties can backfire when stakeholders leave the forum in consequence thereof. ${ }^{161}$ Brunée identifies 'self-help' measures to be potentially reactive, confrontational, and eroding long-term legitimacy of the climate governance framework. ${ }^{162}$ Another problem is that even when there is an erga omnes obligation upon individual states, it is difficult to effectively invoke their breach. ${ }^{163}$ Also, any potential breach will be difficult to settle through disputes because breach of duty, even of an erga omnes nature, does not mean that the injured party has an automatic access to courts. ${ }^{164}$

The compilation by the ILA of climate law principles and the commentaries thereto closely echoes the position outlined above. As mentioned previously, the ILA document notes the common concern of humankind as a goal, thereby giving it an overarching status as a guide. While noting the universal agreement that climate change is a common concern of humankind, the commentary declares that "[...] all states have a common responsibility to take appropriate measures to address the concern". 165 Furthermore, the common responsibility is to be discharged 'through' the principles of sustainable development, common but differentiated responsibility (СBDR), equity, and international cooperation. With respect to sustainable development, the commentaries note the

159 Jutta Brunnée, 'The Global Climate Regime: Whither Common Concern?' [2012] Coexistence, Cooperation and Solidarity (2 vols.) 721,731 . We revisit this issue in Chapters 3 and 6.

16o Shelton (n 156) 39; Horn (n 149) 3 o.

161 Amanda M Rosen, "The Wrong Solution at the Right Time:The Failure of the Kyoto Protocol on Climate Change' (2015) 43 Politics \& Policy 30; Christopher Napoli, 'Understanding Kyoto's Failure' (2012) 32 sAIs Review of International Affairs 183.

162 Brunnée, 'The Global Climate Regime' (n 159) 725.

163 ibid 724; French (n 137) 352-354; Zaker Ahmad, 'State Responsibility Aspects of a Common Concern Based Approach to Collective Action' in Samantha Besson (ed), International responsibility: essays in law, history and philosophy (Schulthess, éditions romandes 2017). Further discussion on this issue can be found in Chapter 6 below.

164 Shelton (n 156) 39; French (n 137) 353.

165 Murase and others (n 131) 4. 
importance of concerted action on the basis of common concern but propose the execution of such action in the broader context of sustainable development. ${ }^{166}$ Similarly, with respect to CBDR, it is submitted that common concern is the basis of the common responsibility part of it, while the incontrovertible operation of the principle of equitable burden-sharing leads to differentiated responsibility. ${ }^{167}$ We recall these terms of interaction between the key foundational principles in the final section of this chapter while suggesting implications for LCT diffusion.

It is submitted that although the above formulation of the legal implications of common concern is neatly squared off with the structure of international law in general and the climate regime in particular, it falls short of resolving the concern. The case on point is the concern of climate change. At the beginning of this chapter, it was outlined that a climate regime built upon voluntary, bottom-up commitments is not strong enough to generate sufficient ambition. ${ }^{168}$ There is a potential in the notion of common concern to be read as requiring a specific end goal to be achieved. With respect to climate change that goal must be, among others, keeping within a safe carbon budget by the end of the twenty-first century. If a facilitative compliance-based regime does not lead there, the obligation to resolve the concern should further necessitate and justify complementary actions that contribute to reaching that goal. It is explained below how the proposed doctrine of Common Concern of Humankind may lead us down that path.

\section{$\mathbf{V}$ \\ Towards a New Doctrine}

Reflecting upon the potential of the common concern norm to evolve further, Thomas Cottier and co-authors promoted a well-calibrated set of propositions to add to the core meaning and consequence of the notion. ${ }^{169}$ The term

\footnotetext{
166 ibid 6-7.

167 ibid 14-20.

168 See section I at p. 6 and onwards.

169 Cottier and others, 'The Principle of Common Concern and Climate Change' (n 147); Thomas Cottier and Krista Nadakavukaren Schefer, 'Responsibility to Protect (R2P) and the Emerging Principle of Common Concern' in Peter Hilpold (ed), The Responsibility to Protect (R2P): A new Paradigm of International Law? (Martinus Nijhoff Publishers 2014); Thomas Cottier, 'Improving Compliance: Jus Cogens and International Economic Law' in den Maarten Heijer and Harmen van der Wilt (eds), Netherlands Yearbook of International Law 2015: Jus Cogens: Quo Vadis? (TмC Asser Press 2016); Thomas Cottier and Tetyana Payosova, 'Common Concern and the Legitimacy of the wTo in Dealing with Climate
} 
'doctrine of Common Concern' is used throughout the volume to indicate the set of broad procedural and substantive responsibilities to be applicable in a clearly defined factual setting as proposed by the author. ${ }^{170}$ Doctrinal scholarship as such, in the tradition of public international law's founding fathers like Vattel or Grotius, plays an important role in the progressive development of international law, ${ }^{171}$ even when not serving as the principal source of law in traditional terms. ${ }^{172}$

In addition to supplying specific thresholds for determining the boundary of a Common Concern, the doctrine further argues that when a matter of shared interests finds itself to be of 'Common Concern', it must be resolved through cooperative means. Beyond this already established duty to cooperate, another avenue of action is the homework responsibility to appropriately address concerns within respective jurisdictional boundaries. ${ }^{173}$ By doing so, the doctrine adds another layer of action, which is of due diligence nature, making sure that any outcome of cooperation is followed upon by the stakeholders with necessary implementation steps. Furthermore, compliance with a Common Concern is ensured not only in a facilitative process but also with unilateral sanctions and countermeasures as the last resort, when necessary and appropriate. ${ }^{174}$

Before venturing further into detailing the different consequences suggested by the doctrine, some attention is due upon the legal nature of the proposed Common Concern norm. The doctrine holds that Common Concern can eventually emerge as a principle of law. Legal principles are unique in their balance between precision and scope of application. The more widely applicable a principle is, the more general tends the terms of its framing to be. ${ }^{175}$ From that perspective, although the doctrine of Common Concern would suggest

Change' in Panagiotis Delimatsis (ed), Research handbook on climate change and trade law (Edward Elgar 2016); Cottier, 'The Principle of Common Concern of Humankind' ( $\mathrm{n} 7$ ).

170 Specific reference to the doctrine itself or the framework of action thereof is distinguished by using the term 'Common Concern' in title case.

171 Alain Papaux and Eric Wyler, 'Legal Theory as a Source of International Law: Doctrine as Constitutive of International Law' in Samantha Besson and Jean d'Aspremont (eds), The Oxford Handbook of the Sources of International Law, vol 1 (Oxford University Press 2018) 524-525 (in print book) <http://oxfordhandbooks.com/view/10.1093/law/ 9780198745365.001.00o1/law-978o198745365-chapter-25> accessed 25 October 2020.

172 As is well known, Article 38 of the Statute of the International Court of Justice, teachings of the 'most highly qualified' publicists from various nations, may only serve as 'subsidiary means' of determining the rule of law.

173 Cottier, 'The Principle of Common Concern of Humankind' (n 7) s 1.6.

174 ibid s 1.7.

175 Ronald Dworkin, 'The Model of Rules' (1967) 35 University of Chicago Law Review 14. 
avenues of action, the actual implementation of these avenues with respect to specific concerns need to be adapted to the exigencies of each regime the doctrine is introduced to. As Cottier mentions:

Conceptualising Common Concern of Humankind as a principle thus seeks to expound underlying values, broadly defined rights and obligations the application of which depends upon a particular context; accordingly results may vary within the broad framework of the principle. We thus should not expect a detailed set of rules commensurate with the principle. This does not exclude that the principle and its components eventually will produce more detailed and specific rules which may further refine its contents and provide enhanced legal security in different fields of the law. ${ }^{176}$

With that being mentioned, following is a brief account of the scope of the proposed notion and all three avenues of legal consequences suggested to be emanating therefrom.

\section{A A Dynamic Gateway for 'Common Concerns'}

It has been already mentioned that common concern of humankind is an identifier for threats on a massive scale that challenge human communities and therefore necessitate collective responses. The Common Concern doctrine further supplies a structured framework that links the expression to the theory of collective action failure to produce global public goods (GPG s) ${ }^{177}$ for identification purposes. The linkage is useful to distinguish true cooperation problems (e.g. climate change) from issues of mere coordination between parties (e.g. global standard setting), or issues where effort by one is globally optimal (e.g. space research). ${ }^{178}$ Conceptualisation of the expression along these lines enjoys the benefit of combining existing legal scholarly work with similar theories in other disciplines, especially economics, resulting in a robust factbased criterion enabling interpretation of the concept in existing and also in new circumstances.

Given that the doctrine prescribes for enhanced responsibility for all stakeholders to resolve a Concern, only exceptional collective action failures merit

176 Cottier, 'The Principle of Common Concern of Humankind' (n 7) s 1.3.2.

177 Cottier and others, 'The Principle of Common Concern and Climate Change' (n 147) 308309, 313; Cottier, 'The Principle of Common Concern of Humankind' (n 7) s 1.4.1.

178 Scott Barrett, Why Cooperate?: The Incentive to Supply Global Public Goods (paperback ed, Oxford University Press 2010). 
falling within the scope of its terms. Cottier further suggests that the boundaries of Common Concern be linked to a high enough threshold that only the extraordinary crises may clear. In this regard, it has been advanced that global peace and stability can serve as the bar. ${ }^{179}$ Global peace, stability, and welfare are not understood in the sense of only non-aggression and avoidance of war, but as a fundamental precondition necessary to maintain human society. 180 Only the problems that eventually threaten peaceful coexistence and welfare globally may be considered as a Common Concern of Humankind. ${ }^{181}$ This way, the authors turn common concern into a dynamic term, the material scope of which may expand over time, ${ }^{182}$ including transboundary resource-related collective action problems, and potentially also economic activities with strong international interdependence. ${ }^{183}$

A well-drawn conceptual boundary of Common Concern helps to liberate the notion from being exclusively subject to a political choice made by parties under the dictates of expediency. Even when operating on a recognised plane of common concern of humankind, i.e. climate change, a designated boundary is helpful especially to limit the influence of the concept upon other regimes. For example, measures taken in the trade regime can be helpful for climate mitigation, adaptation, or necessary transfer of technology. But according to the doctrine, a responsibility to take such measures, or to cooperate to that effect would only exist to the extent such steps do bear a clear and manifest linkage with the defined boundary of the Common Concern.

\section{B Enhanced Legal Consequences}

The doctrine advances three distinct, yet interrelated channels guiding the stakeholders' responses regarding all Common Concerns of Humankind. ${ }^{184}$ The responsibility to cooperate, coupled with the duty to take appropriate domestic measures at home (i.e. homework) arise at the very outset with the emergence of a Common Concern. ${ }^{185}$ In situations where effective cooperation

\footnotetext{
179 Cottier, 'The Principle of Common Concern of Humankind' (n 7 ) s 1.3.2.4.

180 ibid.

181 ibid.

182 Cottier and Payosova (n 169) 14.

183 Cottier, 'Improving Compliance:Jus Cogens and International Economic Law' (n 169) 350; Cottier, The Prospects of Common Concern of Humankind in International Law (n 5). See various case studies in that volume.

184 Cottier and others, 'The Principle of Common Concern and Climate Change' (n 147) 314320; Cottier, 'The Principle of Common Concern of Humankind' (n 7) ss 1.5-1.7.

185 Cottier, 'The Principle of Common Concern of Humankind' (n 7) ss 1.5-1.6.
} 
is unsuccessful or homework is not forthcoming, the doctrine further advances a duty to undertake unilateral measures to secure compliance. ${ }^{186}$

These normative consequences undoubtedly push beyond the traditional meaning of common concern of humankind elaborated earlier. ${ }^{187}$ It happens in at least two specific ways. One is the way the doctrine proposes legal consequences arising exclusively out of the legal expression. In the treaty frameworks already deploying the notion (e.g. climate change or biodiversity), obligations such as cooperation and due diligence co-exist with the expression. ${ }^{188}$ The doctrine turns this co-existence into causation, making it possible for the consequences to be invoked also in situations where a 'Common Concern' exists in the absence of a treaty. Another way in which the doctrine goes beyond its traditional understanding is the way the consequences are formulated. Instead of declaring the states' freedom to take action to resolve Common Concerns, the doctrine binds them under a positive duty. This duty to act lies at the heart of the proposed framework, influencing all the three avenues of normative consequences arising therefrom. ${ }^{189}$

Even though the doctrine suggests threefold consequences, some primary conclusions already indicate that all three aspects may not come into play in all the fields of law. The nature of the subject-matter may not always merit for efforts along the three avenues. For example, Lucia Satragno's work on monetary regulation as a Common Concern of Humankind shows that unilateral compliance securing measures currently has very little to do in that area. ${ }^{190}$ The following paragraphs elaborate upon the enhanced normative consequences and their relevance in international trade regulation and diffusion of LCT $\mathrm{s}$.

\section{Responsibility to Cooperate}

As mentioned before, collective responsibility towards cooperation internationally is the undisputed, as well as an indispensable consequence of common concern of humankind. It is nevertheless important to explicitly mention so because international law is punctuated by respect for sovereign equality.

\footnotetext{
186 ibid 1.7.

187 See pp 34-36 above.

188 With respect to the international climate change law, scholars see 'no harm' rule as having a customary status. This gives rise to homework obligations like due diligence, and procedural obligations like duty to consult, negotiate and cooperate. For details, see, Bodansky, Brunnée and Rajamani (n 129) 40-43.

189 Cottier, 'The Principle of Common Concern of Humankind' ( $n_{7}$ ) s 1.7.3.

190 Lucia Satragno, 'International Monetary Stability as a Common Concern of Humankind' in Thomas Cottier (ed), The Prospects of Common Concern of Humankind in International Law (Cambridge University Press 2020) s 1.6.
} 
A duty to cooperate does not ordinarily exist unless provided for in express terms. So far, such duties exist within limited frames, e.g. duty to negotiate in good faith at the wто, or a duty to settle disputes peacefully. The doctrine of Common Concern indicates that a responsibility to cooperate entails engaging in consultation and negotiation in a transparent manner and with good faith. ${ }^{191}$ Such cooperation would eventually result in the building of appropriate institutions to tackle and respond to the concern. ${ }^{192}$ With respect to climate change, principles of equity, sustainable development, and differentiated responsibility would inform any cooperation approach. The evolving climate governance framework amply exemplifies this point.

It should be emphasised that the responsibility to cooperate is not solely an obligation of conduct. To be successful, parties to cooperation must do more than merely engage. It must result in specification of the appropriate range of actions to be taken by the stakeholders at different levels of governance. It also means that cooperation itself must not be limited to a specific level or certain type of actors. Again, with respect to climate change, it is important that cooperation spans across institutions, fostering a coherent response to the problem. Cooperation is the basis on which further synergy between the trade and the climate regimes can be built up. Chapter 3 of this volume elaborates upon the dimensions of cooperation in pursuance of the doctrine of Common Concern, focusing on the role of states, and specific to the issue of low-carbon technology diffusion.

Homework Responsibility

Noting that cooperation alone is insufficient to address any shared concern successfully, the doctrine further calls for necessary actions to be taken within the domestic legal system. Although it is an increment upon current understanding of the legal implication of common concern, it is in no way unreasonable. The common concern of humankind is already understood as limiting the policy autonomy of the sovereign entities with respect to an area of shared concern. ${ }^{193}$ This constraint, in itself, is an obligation to make policy choices that cater to addressing a concern and not worsening them. For example, with respect to climate change, the limitation of not worsening the concern would translate into supplying incentives to the renewables industries instead of fossil fuels. The homework obligation as proposed by the doctrine of Common Concern offers to change the current mere encouragement to act (right to act)

\footnotetext{
191 Cottier, 'The Principle of Common Concern of Humankind' (n 7) s 1.5.2.

192 ibid.

193 See p 36 (nn 156-7) above.
} 
following the expression of concern to a positively worded obligation to act in response to the problem.

The environmental principles of 'no harm' and 'due diligence' informs the homework obligation to a great extent. ${ }^{194}$ Harm prevention is akin to the constraining function of common concern mentioned above. The principle of due diligence conditions the application of any further positive obligation envisaged by the doctrine. As a result, appropriate homework measures are required to be taken only after consideration of the reality faced by each country, their capacity, ability to discharge positive obligations, as well as the availability of support.

Within the trade regime, the nature and extent of homework obligations would depend on the legal framework actually in place. Thomas Cottier in his work highlights two ways of implementing homework obligations-through the domestic performance of international obligations, or by adopting autonomous measures. In the former case, Common Concern doctrine should inspire further trade rulemaking relevant to the area of application (e.g. technology diffusion) through a cooperative process. Where there are such rules, homework obligation may only entail carrying them out informed by the tenets of multi-level governance (the principle of subsidiarity, in particular) ${ }^{195}$ In the absence of detailed regulation, autonomous trade measures are to be taken to address a Common Concern. This category of actions, when challenged, would possibly fall back on the notion itself for necessary legitimation. In case any such action is challenged in a formal dispute, the question would arise whether the principle of Common Concern of Humankind and the suggested normative implications thereto can be taken to form part of the applicable law. This last answer truly depends upon the development and acceptance of the doctrinal approach through claims and responses, as the next section would elaborate.

It is nevertheless true that matters that touch upon trade, e.g. regulating production and consumption, may also indirectly moderate the behaviour of trading partners. This is highlighted by Cottier as the extraterritorial impact of domestic regulation. Such impacts should be necessary and welcome so long as those are not employed to meet protectionist ends. Subsequent chapters of

194 The International Court of Justice held that the obligation of prevention arises from the due diligence required of a State, Case concerning Pulp Mills on the River Uruguay (Argentiva v Uruguay) (Judgment) [2010] ICJ Rep 14 (International Court of Justice); For a detailed discussion, see, Birnie, Boyle and Redgwell (n 145) 137-15o; With particular reference to climate change, see, Bodansky, Brunnée and Rajamani (n 129) 41-42.

195 Chapter 3 , sections II, \& III provides further details in this regard. 
this volume explore the detailed aspects of the homework obligation. A number of useful domestic trade policy measures are identified in Chapter 3 . Thereafter, Chapters 4 and 5 look at specific technology diffusion policy measures and their relations with trade regulation and the doctrine of Common Concern.

(iii) Securing Compliance

While the duty to act influences all the normative aspects of the doctrine, it perhaps goes farthest and draws most scepticism in response when applied to the aspect of securing compliance unilaterally. The doctrine of Common Concern dictates that as a last resort, non-compliance with the proposed normative framework must be met with unilateral countermeasures. In practical terms, it therefore implies that the willing and able actors are under a positive obligation to act unilaterally seeking to correct the behaviour of their noncompliant counterparts. ${ }^{196}$

Unilateral countermeasures become obligatory in cases where noncooperation arises from parochial, self-interested motivation. It is not attracted in situations where the failure of an actor to comply with the dictates of the doctrine stem from lack of capacity or other reasonable shortcomings. We further recall that support and assistance remain essential corollaries to cooperation and homework parts of the framework. It is nevertheless true that the legitimisation of any such countermeasure would require the state responsibility rules regarding the definition of the injured state to change. The benefit of the proposition is that not only does it serve as a final recourse to bring the fractious cohorts back to cooperation, it further offers to discipline unilateral action, which currently takes place in a grey area of public international law. ${ }^{197}$

Chapter 6 of this volume discusses that the aspect of compliance enforcement through unilateral countermeasures, like the homework aspect of Common Concern, would depend on the existing contextual legal framework. It would also depend on the actual nature of the breach itself. In case explicit regulations inspired by the doctrine are put in place within a treaty framework, a breach thereof would first and foremost require taking resort to the mechanism established within such frameworks to address non-compliance. Whether a compliance mechanism would accommodate taking of unilateral countermeasures as proposed here would depend on the specifics of each situation. Also importantly, in an era where multilateralism is threatened to be

196 Cottier, 'The Principle of Common Concern of Humankind' (n 7) s 1.7.3.

197 Ibid s 1.7.1. 
abandoned in favour of populist and mercantilist policies, abundant caution is required while advancing a proposition that calls upon the powerful states to act unilaterally.

In situations where the primary obligations of cooperation and homework have not resulted in express substantive commitments from the parties to a treaty framework, the call for compliance using unilateral countermeasure would have a smaller scope of legitimacy. However, unilateral steps as such would nonetheless be required as part of a 'carrot and stick' approach, to induce all the involved parties to come to the negotiations table, also to take diligent homework measures. The legitimacy of this approach would depend on the success of the argument that refusals to cooperate and undertake homework measures breaches obligations of erga omnes character arising out of the Common Concern of Humankind doctrine.

\section{Forward Evolution}

Although the Common Concern doctrine potentially supplies an integrated framework to deal with critical collective action challenges with global public goods (GPG S) as they arise, it should be noted that it is an evolving process. The gradual fostering of Common Concern of Humankind as a norm entailing stricter legal consequence would take place through 'claims and responses' in the international field. ${ }^{198}$ Nolte similarly mentions that community norms do not automatically manifest themselves. Often they are results of claims made by an actor, which then gathers salience due to political or other forms of suasion. ${ }^{199}$ Eventually, some or all aspects of the doctrine may obtain a status of a customary or a general principle of international law, of an erga omnes nature.

Principles are flexible instruments that suggest a general standard of conduct. ${ }^{200}$ The positive aspect of construing the doctrine of Common Concern as a future principle of international law is that it remains possible to envisage its application in a variety of factual settings. ${ }^{201}$ This adaptability, as previously

\footnotetext{
198 Ibid s 1.3.1.

199 Nolte (n 129) 103; This is similar to what Finnemore and Sikkink identified as norm entrepreneurship, Martha Finnemore and Kathryn Sikkink, 'International Norm Dynamics and Political Change' (1998) 52 International Organization 887, 895 .

200 Dworkin (n 175); Jutta Brunnée, 'The Rule of International (Environmental) Law and Complex Problems' in Heike Krieger, Georg Nolte and Andreas Zimmermann (eds), The International Rule of Law: Rise or Decline? (Oxford University Press 2019). The author maintains that principles like customary principles like harm prevention are not by themselves sufficient to tackle complex global challenges. The latter requires development of treaty regimes.

201 See pp. 40-1 above.
} 
mentioned, comes at the cost of specificity. Principles colour the application of rules, or inspire the making of new ones that eventually operationalises the expression in the real world. Admittedly, therefore, even when Common Concern of Humankind is considered as a principle of international law, its application in a specific setting would probably require new rules, or understanding the existing ones in its light. It remains possible for a multilateral or a regional treaty regime to adopt the doctrine as a guiding principle in part or full, thereby turning it into an erga omnes partes. ${ }^{202}$ In so doing, manifestation of the doctrine's proposition in different regimes would vary.

Unlike international lawyers, international relations scholars, especially the social constructivists closely study the evolution of norms. Some insight may be obtained therefrom. Finnemore and Sikkink, in their work, indicate three key stages in the life-cycle of a norm, namely norm creation, norm cascade, and norm internalisation. ${ }^{203}$ The authors hold that available literature generally concur on two elements for successfully creating a new norm, i.e. having norm entrepreneurs and the existence of an organisational platform. New norms do not emerge from a vacuum. It is rather the existing ones that evolve and take up new meaning. The norm entrepreneurs serve as 'meaning architects' or suppliers of a new 'frame' of interpretation. ${ }^{204}$ The evolution of the doctrine of Common Concern can be contemplated along the same line. At the initial stage the norm entrepreneurs need not necessarily be the states. Different non-state actors can organise and disseminate the utility of a norm at various levels of governance. Eventually, however, state endorsement would be necessary for a norm to eventually gather enough salience to be able to pass a 'tipping point' beyond which it becomes self-reliant. ${ }^{205}$ That arguably is the point when the norm formally enters the domain of hard law.

It remains a hypothesis of this research that this doctrinal structure may assist in generating a more coherent trade and climate regime and in the process facilitate diffusion of LCT. The following section ventures to outline that process.

\section{vi Application in the Trade-Climate Interface}

So far we have concluded that the trade and the climate regimes have key differences in terms of subject-matters, goals, and core principles. While the

\footnotetext{
202 Brunnée, 'The Global Climate Regime' (n 159) 724.

203 Finnemore and Sikkink (n 199) 895.

204 ibid 897.

205 ibid 900-9o1.
} 
differences lead to a potential of fragmentation between these two regimes, both have the seeds of mutual cooperation planted in them in the form of a common subscription to sustainable development. ${ }^{206}$ Here we initiate application of the proposed doctrine of Common Concern of Humankind upon the incomplete trade-climate coherence building agenda, on which the subsequent chapters will build upon.

We recall that one of the key goals of this research is to introduce the doctrine of Common Concern to the multilateral trade regime with respect to the latter's dealings with climate change. ${ }^{207}$ Trade itself is not a Common Concern of Humankind. It forms part of a shared dialogue under the rubric of the Common Concern doctrine only to the extent the WTo law and domestic trade policy measures have an exclusive role to take the climate agenda forward. The doctrine would facilitate better framing of trade-related response measures to climate change. The framing would prioritise coherence by balancing the competing values, as well as preserving the alignment of the guiding norms that define the relationship between the climate and the trade regimes. As we would see later with respect to the diffusion of clean technologies, a coherent trade and climate change agenda has much more to do with harmonised and complementary actions than merely using trade as a means of threat. ${ }^{208}$ The act of trade is in itself a facilitative and mutually beneficial endeavour. Questions of unilateral intervention, if ever arising, would only be to tackle instances of egregious non-cooperation.

Also, this research does not deal with the entirety of the space of Common Concern of climate change in the trade field. As already detailed, it addresses the issue of LCT diffusion. Technology development and transfer is not an entirely new issue in the trade regime, especially when the issue touches upon intellectual property protection. As already mentioned, technology transfer can take place spontaneously, as well as through implementation of specific North to South support obligations. Transfer of technology in general is not seen as a Common Concern here. What is a Common Concern of Humankind is the inhibition of wide diffusion of low-carbon technologies, particularly to the developing and the least-developed countries, as it hinders effective, adequate, and timely climate mitigation from taking place globally.

Until a principle of Common Concern of Humankind attains a customary status under public international law, it can influence rulemaking in other

\footnotetext{
206 See p. 23-4 above.

207 There can be other Common Concerns that may have a bearing upon trade rules. See, Schaeli (n 143).

208 See Chapter 3, section II A below.
} 
treaty regimes like the WTO through express incorporation into the body of treaty rules. The doctrine can also be utilised to interpret existing trade regulation applied with respect to climate change. However, despite originating from a recognised principle of climate law, Common Concern is yet to garner evidence of use and practice by the states in international relations like the principle of sustainable development.

\section{A Terms of Relationship with Key Notions}

The doctrine of Common Concern needs to be squared off with the current normative basis of synergistic understanding between the two regimes, namely the principle of sustainable development. It is well understood that the principle of sustainable development "add[s] colour and texture" to the commitments of the covered agreements of the што. ${ }^{209}$ It also sits at the heart of the global sustainable development goals (SDG s) endorsed by the United Nations, including inter alia, the goal of ensuring sustainable production and consumption patterns (Goal 12), ${ }^{210}$ and the goal of climate action (Goal 13). ${ }^{211}$ The question is whether the introduction of Common Concern is in any way subversive to the state parties' commitment to the principle of sustainable development. Similar attention is also required with respect to reconciling Common Concern with the principle of differentiated responsibility.

The doctrine of Common Concern will only supplement the integrative and conciliatory role of sustainable development. ${ }^{212}$ The role of Common Concern is to introduce a special emphasis on certain issues from the bulk that are within the panoply of sustainable development. It is submitted that due to the factual circumstances mentioned at the beginning of the chapter, climate change indeed deserves a more than equal share of attention compared to the

209 United States - Import Prohibition of Certain Shrimp and Shrimp Products (n 94) para 153; See, for more, Christina Voigt, 'Delineating the Common Interest in International Law' in Wolfgang Benedek and others (eds), The common interest in international law (Intersentia 2014); Elisabeth Bürgi Bonanomi, Sustainable Development in International Law Making and Trade: International Food Governance and Trade in Agriculture (Edward Elgar 2015).

210 United Nations General Assembly, 'Transforming Our World: The 2030 Agenda for Sustainable Development' (United Nations 2015) A/REs/70/1. Goal ${ }_{12} \mathrm{C}$ specifically asks to '[r]ationalize inefficient fossil-fuel subsidies that encourage wasteful consumption by removing market distortions, in accordance with national circumstances, including by restructuring taxation and phasing out those harmful subsidies, where they exist, to reflect their environmental impacts, taking fully into account the specific needs and conditions of developing countries and minimizing the possible adverse impacts on their development in a manner that protects the poor and the affected communities'.

211 ibid.

212 See p. 37 above. 
other environmental issues, as well as a quicker and stronger response from all stakeholders. The Common Concern doctrine carries that sense of urgency from the climate change regime and brings it to the trade world. While all the environmental issues coming to the trade regime also come under the fold of sustainable development, not all of them will be considered as Common Concerns. Therefore the doctrine can be used to create an exclusive narrative commanding immediate action to be taken regarding climate change in the trade regime. This can be of use to all the sticking climate-related issues, including that of LCT diffusion.

Respect for differentiated responsibility should also be a part and parcel of implementing the doctrine of Common Concern in trade law. The nature of differentiated responsibility under climate law is slightly different from the special and differential treatment commitments that exist in the WTO covered agreements. The principle of common but differentiated responsibility (CBDR) is a mainstay of the climate regime. While earlier the СвDR entailed a strict bifurcation of responsibility among the Annex-I countries and others as identified in the UNFCCC, over time it has become more dynamic in nature. The doctrine of Common Concern, as well as the wTo law and trade policy attracted under its fold, must be attendant to the demands of this principle. As explained in relation to the homework obligation under the Common Concern doctrine, domestic trade policy measures to facilitate climate action must take place with appropriate considerations for their impact on developing countries. It is all the more important when such measures would entail costs upon the latter. Appropriate settlements of such concerns are only possible through cooperation, which is why equitable consideration plays a core role in the new cooperation agenda outlined later. ${ }^{213}$ However, differentiated responsibility should not be taken as an excuse for any actor to shirk off climate responsibility. It would rather be important that the specific needs of the countries are communicated and appropriate assistance provided to ramp up global action.

\section{B Implications for Low-Carbon Technology Diffusion}

To the extent diffusion of low-carbon technology is a part of the Common Concern, not only would the doctrine suggest for adequate steps to be taken to deal with any existing barriers preventing such diffusion, but it would also call for actions to positively incentivise technology related transactions. This research is devoted to that effect. At this moment, it can only be hypothesised that obligations arising out of the doctrine, i.e. international cooperation and

213 See p. 125-7 below. 
domestic steps to tackle market barriers, as well as to promote the growth of related industries will have a positive impact upon the diffusion of low-carbon technologies worldwide. To test it out, awareness of the details of current legal and institutional settings, as well as an empirically sound knowhow of the nature of the technology diffusion challenge, is paramount. The next chapter will turn to those issues.

\section{Conclusion}

This inaugural chapter has supplied a succinct account of the research problem and the theoretical framework, specified the scope of research, and provided a brief glimpse into the coming analysis. It has been shown that climate change is a complex problem, which the current body of rules, including the recently concluded Paris Agreement, remain incapable of addressing. Part of that inability affects the diffusion of LCT s, which is the particular topic of research here. The chapter has also highlighted that various sub-disciplines of IEL, international trade law for example, provide for avenues through which clean technologies are spread across borders. Focusing on international trade, it was argued that trade policy interventions are necessary to enhance the technique effect of trade opening to lower aggregate GHG emissions, to help countries assume responsibility for consumption emissions, and also importantly, to tackle price and incentive related market imperfections that hinder diffusion of clean technologies. However, the reality is that appropriate coherence between trade and climate regimes remain incomplete.

Against this backdrop, the chapter has characterised low-carbon technology diffusion in the light of the legal doctrine of Common Concern of Humankind, proposing tripartite obligations as emanating from it - (i) duty to cooperate, (ii) homework obligations, and (iii) unilateral enforcement through trade countermeasures. It is maintained that subject to the fulfilment of the requirements of state practice, the doctrine can become a future customary principle, or be incorporated into a treaty regime. It is also found that the Common Concern doctrine can make progress upon the incomplete agenda of coherence between the trade and climate regime by supplementing the already applicable principle of sustainable development, and side by side maintaining respect for differentiated responsibility. To the extent that the diffusion of LCT s suffer from trade-related obstacles, it comes under the umbrella of Common Concern and obtains benefit from the novel framing introduced by the doctrine. 